\title{
Intra-clinothem variability in sedimentary texture and process regime recorded down slope profiles
}

LIST OF AUTHORS: GRACE I.E. COSGROVE ${ }^{1 *}$, MIQUEL POYATOS-MORÉ ${ }^{2}$, DAVID LEE ${ }^{1}$, DAVID M. HODGSON $^{1}$, WILLIAM D. MCCAFFREY ${ }^{1}$, NIGEL P. MOUNTNEY ${ }^{1}$

\section{LIST OF ADDRESSES:}

${ }^{1}$ School of Earth and Environment, University of Leeds, Leeds LS2 9JT, United Kingdom

${ }^{2}$ Department of Geosciences, University of Oslo, 0371 Oslo, Norway

*CORRESPONDING AUTHOR: eegiec@leeds.ac.uk

Associate Editor - Massimiliano Ghinassi

Short Title - Intra-clinothem variability down slope profiles

\section{ABSTRACT}

Shelf-margin clinothem successions can archive process interactions at the shelf to slope transition, and their architecture provides constraints on the interplay of factors that control basin-margin evolution. However, detailed textural analysis and facies distributions from shelf to slope transitions remain poorly documented. This study uses quantitative grain-size and sorting data from coeval shelf and slope deposits of a single clinothem that crops out along a $5 \mathrm{~km}$ long, dip-parallel transect This article has been accepted for publication and undergone full peer review but has not been through the copyediting, typesetting, pagination and proofreading process, which may lead to differences between this version and the Version of Record. Please cite this article as doi: $10.1111 /$ sed. 12648

This article is protected by copyright. All rights reserved. 
of the Eocene Sobrarbe Deltaic Complex (Ainsa Basin, south-central Pyrenees, Spain). Systematic sampling of sandstone beds tied to measured sections has captured vertical and basinward changes in sedimentary texture and facies distributions at an intra-clinothem scale. Two types of hyperpycnal flow, related slope deposits, both rich in mica and terrestrial organic matter, are differentiated according to grain size, sorting and bed geometry: (i) sustained hyperpycnal flow deposits, which are physically linked to coarse channelized sediments in the shelf setting and which deposit sand down the complete slope profile; (ii) episodic hyperpycnal flow deposits, which are disconnected from, and incise into, shelf sands and which are associated with sediment bypass of the proximal slope and coarse-grained sand deposition on the medial and distal slope. Both types of hyperpycnites are interbedded with relatively homogenous, organic-free and mica-free, well-sorted, very fine-grained sandstones, which are interpreted to be remobilized from wave-dominated shelf environments; these wave-dominated deposits are found only on the proximal and medial slope. Coarse-grained sediment bypass into the deeper-water slope settings is therefore dominated by episodic hyperpycnal flows, whilst sustained hyperpycnal flows and turbidity currents remobilizing wavedominated shelf deposits are responsible for the full range of grain-sizes in the proximal and medial slope, thus facilitating clinoform progradation. This novel dataset highlights previously undocumented intra-clinothem variability related to updip changes in the shelf process-regime, which is therefore a key factor controlling downdip architecture and resulting sedimentary texture.

\section{INTRODUCTION}

Clinothems typically form progradational basin margin successions (e.g. Gilbert, 1885; Rich, 1951; Asquith, 1970; Mitchum et al., 1977; Pirmez et al., 1998; Adams \& Schlager, 2000; Bhattacharya, 2006; Patruno et al., 2015). Seismic reflection and well-log data have been used extensively to study subsurface clinothem successions (e.g. Ross et al., 1995; Pinous et al., 2001; Donovan, 2003; Jennette et al., 2003; Hadler-Jacobsen et al., 2005). However, outcrop examples of clinothems offer a higher-resolution record of stratigraphic and downslope clinothem evolution (e.g. Helland-Hansen, 1992; Dreyer et al., 1999; Pyles \& Slatt, 2007; Pontén \& Plink-Björklund, 2009; Hubbard et al., 2010; Dixon et al., 2012a; Jones et al., 2013; Poyatos-Moré et al., 2019). Exhumed clinothem successions provide the opportunity to document patterns of facies distribution and sedimentary texture. This information can be used to help constrain the interplay of controls on clinothem evolution (e.g. Mellere et al., 2002; Plink-Björklund \& Steel, 2003; Carvajal \& Steel, 2006; Pyles \& Slatt, 2007; Jones et al., 2015; Laugier \& Plink-Björklund, 2016). However, predicting facies distributions and

This article is protected by copyright. All rights reserved. 
sedimentary textures within individual clinothems, both vertically and along depositional dip, remains challenging (Cosgrove et al., 2018). In part, this is due to the lack of detailed, quantitative grain size and sorting datasets recovered from clinothem sequences, which has left down-clinothem changes in grain size and sorting as poorly constrained and largely unquantified parameters (Catuneanu et al., 2009).

Prediction of sedimentary texture along a continuous clinothem depositional profile is further complicated by changes in the dominant shelf process-regime (cf. Dixon et al., 2012b; Laugier \& Plink-Björklund, 2016; Cosgrove et al., 2018). Process-regime affects how and when sediment of different calibre and maturity is transferred downdip (Dixon et al., 2012b; Cosgrove et al., 2018). Sudden changes in shelf process-regime can occur over intra-clinothem timescales (Ta et al., 2002; Ainsworth et al., 2008; Plink-Björklund, 2008; Carvajal \& Steel, 2009; Vakarelov \& Ainsworth, 2013; Jones et al., 2015). Despite this, mixed-energy clinothems systems are under-represented in the literature (see Ainsworth et al., 2011; Olariu, 2014; Rossi \& Steel, 2016) and clinothems are therefore commonly designated as being end-member types (i.e. river-dominated, wave-dominated or tidedominated, systems) (e.g. Dreyer et al., 1999; Pink-Björklund et al., 2001; Plink-Björklund \& Steel, 2002; Deibert et al., 2003; Crabaugh \& Steel, 2004; Plink-Björklund \& Steel, 2004; Johannessen \& Steel, 2005; Petter \& Steel, 2006; Sylvester et al., 2012). As such, the impact of mixed processregime conditions on downslope sedimentary texture remains relatively understudied (e.g. Cosgrove et al., 2019).

To improve understanding of process and textural variability within individual clinothem sequences, this study focuses on the Sobrarbe Deltaic Complex, an outcrop example of well-constrained clinothems, located in the Eocene Ainsa Basin, south-central Pyrenees, Spain (Fig. 1). This system is ideal for studying quantitative changes in grain size and sorting at high spatial resolution, due to the presence of a series of well-exposed and accessible clinothem sequences, which can be directly correlated from coeval fluvio-deltaic shelf to distal slope deposits (Dreyer et al., 1999). This investigation uses detailed facies analyses and quantitative changes in grain size and sorting to address three overarching questions: (i) how do changes in the dominant shelf process regime affect facies distribution within an individual clinothem sequence; (ii) how do changes in sedimentary texture (including grain size and sorting) vary up-stratigraphy and along depositional dip; and (iii) can quantitative grain-size data be used to identify sediment bypass at the clinoform rollover? This outcrop-based study provides new insights into the evolution of individual clinothems and may be used as a predictive reference for subsurface exploration and basin evolution models.

This article is protected by copyright. All rights reserved. 


\section{GEOLOGICAL SETTING}

The Sobrarbe Deltaic Complex crops out in the western part of the Eocene Ainsa Basin, northeastern Spain (Fig. 1). The Ainsa Basin in the Upper Eocene is a piggyback basin, located in and on top of the easternmost portion of the Gavarnie thrust-sheet-complex, and forms the central sector of the South Pyrenean foreland basin (Vergés \& Muñoz, 1990; Muñoz, 1992; Fernández et al., 2004). The Ainsa Basin is bordered to the west by the Jaca-Pamplona Basin and to the east by the TrempGraus Basin (Puigdefàbregas, 1975; Brunet, 1986). The western part of the basin is characterized by several fold structures that were active during deposition: the Añisclo anticline to the north; the Peña Montañesa thrust to the north-east; the Mediano anticline to the east; the Boltaña anticline to the west (Fig. 2; Poblet et al., 1998; Dreyer et al., 1999; Fernández et al., 2004; 2012).

The fill of the western Ainsa Basin is dominated by a ca $5 \mathrm{~km}$ thick succession of Upper Eocene sediments. As part of these, the Sobrarbe Deltaic Complex (typically ca $800 \mathrm{~m}$ thick) comprises the uppermost part of the San Vicente Formation (marly slope deposits and turbiditic sandstones), the Sobrarbe Formation (shallow-marine deposits), and up to the middle part of Mondot Member of the Escanilla Formation (alluvial red-bed succession) (Van Lunsen, 1970; DeFrederico, 1981; Dreyer et al., 1993; Wadsworth, 1994). These deltaic successions accumulated over a period of ca $3 \mathrm{Myr}$ during the middle Lutetian to lower Bartonian, reaching a maximum thickness of $c a 1 \mathrm{~km}$ (Muñoz et al., 1998).

The Sobrarbe Deltaic Complex comprises a series of well-exposed, ca $100 \mathrm{~m}$ thick clinothems, which crop-out in a $>5 \mathrm{~km}$ long transect, in an approximately dip-parallel orientation. These clinothems show the transition from fluvio-deltaic deposits (Escanilla Formation) in the south to progressively deeper shelf- and slope-deposits (Sobrarbe and San Vicente formations) in the north (Dreyer et al., 1999). Dreyer et al. (1999) subdivided the Sobrarbe Deltaic Complex into five composite sequences: the Comaron, the Las Gorgas, the Barranco el Solano, the Buil and the Mondot Member of the Escanilla Formation (Fig. 3). These composite sequences are separated by major unconformities, which represent fluctuations in relative sea-level (Dreyer et al., 1999).

The composite sequences are in turn subdivided into 'minor sequences' (Dreyer et al., 1999), which comprise sandstones units interbedded with mudstones and marls. The minor sequences are described as genetic sequences, bounded by transgressive surfaces (sensu Galloway, 1989). The first minor sequence of the Las Gorgas composite sequence is the specific focus of this study (Fig. 3).

This article is protected by copyright. All rights reserved. 


\section{METHODS AND TERMINOLOGY}

The term clinoform is used to describe sinusoidal basinward-dipping chronostratigraphic stratal surfaces, whereas the term clinothem is used to describe the sedimentary packages that occur between these surfaces (e.g. Gilbert, 1885; Rich, 1951; Mitchum et al., 1977; Pirmez et al., 1998; Patruno et al., 2015). Clinothems are typically composed of three constituent parts: a geometric shelf (topset deposits; updip, gently basinward dipping), a geometric slope (foreset deposits; central component, seaward-dipping typically at $c a 1$ to $3^{\circ}$ ) and a geometric basin-floor (bottomset deposits; downdip, gently dipping) (Gilbert, 1885; Steel \& Olsen, 2002). The zone of the clinoform rollover denotes an area of gradient increase and is the site of the uppermost break-in-slope between the shelf and slope segments (Van Wagoner et al., 1990; Pirmez et al., 1998; PlinkBjörklund et al., 2001; Glørstad-Clark et al., 2010, Glørstad-Clark et al., 2011; Anell \& Midtkandal, 2015; Jones et al., 2015). Clinothems develop at scales ranging from subaerial delta clinothems (ca tens of metres in height), to basin-margin clinothems (ranging from ca hundreds of metres to $>1 \mathrm{~km}$ in height) (e.g. Pirmez et al., 1998; Steel \& Olsen, 2002; Helland-Hansen \& Hampson 2009; Henriksen et al., 2009; Anell \& Midtkandal, 2015; Patruno et al., 2015; Patruno \& Helland Hansen, 2018).

The rock samples used in this investigation were acquired from the oldest clinothem of the Las Gorgas composite sequence (Figs 2 and 3), hereafter referred to as Cycle LG-1 (Fig. 4), which is continuously exposed in depositional dip for ca $5 \mathrm{~km}$ and which reveals a shelf to slope transect. In Cycle LG-1, seven sample locations were chosen along the continuous depositional profile to provide even down-dip coverage of the shelf to slope transition (Fig. 4).

At each sampling site, detailed sedimentary logs were collected, and between four and seven rock samples were recovered. In total, 36 samples were recovered from Cycle LG-1. The locations of the rock samples were recorded using a handheld GPS and photographed; georeferenced sample locations are included in the Supplementary Material. To ensure consistency and repeatability, and to avoid impact of mudstone clasts, rock samples were recovered from ca $0.1 \mathrm{~m}$ above the base of each sandstone-package.

Small blocks (ca $25 \mathrm{~mm} \times 25 \mathrm{~mm} \times 10 \mathrm{~mm}$ ) were cut from each rock sample; samples were then polished and impregnated with epoxy resin, carbon-coated and placed on a scanning electron microscope (SEM) mount using conductive copper tape. Photomicrographs of samples were taken using a Tescan SEM (Tescan, Brno-Kohoutovice, Czech Republic) at the University of Leeds Electron Microscopy and Spectroscopy Centre. All SEM photomicrographs were taken in backscatter mode at a similar contrast to ensure comparability. The photomicrographs were imported into the image

This article is protected by copyright. All rights reserved. 
processing and analysis program ImageJ, which was used to identify grain boundaries and to calculate grain diameters (e.g. Sumner et al., 2012). Measured grain-diameters ascertained from thin section, or photomicrographs, are smaller than the true maximum grain diameter (e.g. Chayes, 1950, Greenman, 1951; Kellerhals et al., 1975). However, due to the fully-lithified nature of the recovered rock-samples, photomicrograph analysis was deemed to be the most effective grain-sizing methodology. The statistical analysis of all ImageJ results was completed using GRADISTAT computer software (Blott \& Pye 2001), which enables the rapid analysis of grain-size and sorting statistics (e.g. St-Onge et al., 2004; Gammon et al., 2017).

Extensive unmanned aerial vehicle (UAV) photography was collected. Using georeferenced photographs, acquired using a DJI Phantom 3, a photorealistic three-dimensional outcrop model was constructed using the photogrammetric software Agisoft PhotoScan. The resulting model was analysed using the LIME visualisation software (www.virtualoutcrop.com). UVA-footage has enabled the construction of a high-resolution outcrop model, in which Cycle LG-1 can be traced laterally and the sampling locations can be illustrated (Fig. 4).

\section{CLINOTHEM GEOMETRY}

The large-scale and well-exposed nature of the Sobrarbe Deltaic Complex allows the palaeobathymetric position of the shelf, clinoform rollover and slope to be constrained (Fig. 4). Clinothem gradients, as outlined below, are averaged from UAV digital outcrop models (Fig. 4), which represent compacted stratigraphy.

\section{Description}

From Location 1 to 2, Cycle LG-1 has sub-horizontal geometry. From Location 2 to 3 , there is an increase in average clinoform gradient, from sub-horizontal to $c a 4^{\circ}$, associated with an increase in clinothem thickness (Fig. 4). From Location 3 to 4 there is an increase in average clinothem gradient to $c a 8^{\circ}$. From Location 4 to 6 there is a decrease in average clinothem gradient to $c a 5^{\circ}$. From Location 6 to 7 , average clinothem gradient decreases to $c a 2^{\circ}$ (Fig. 4).

\section{Interpretation}

The relatively flat clinothem geometry observed from Location 1 to 2 suggests a shelf (topset) environment (e.g. Steel \& Olsen, 2002; Patruno et al., 2015; Laugier \& Plink-Björklund, 2016). The prominent increase in gradient from Location 2 to 3 is interpreted to define the zone of clinothem rollover (e.g. Pirmez et al., 1998; Glørstad-Clark et al., 2010; Anell \& Midtkandal, 2015); this is

This article is protected by copyright. All rights reserved. 
further supported by the prominent stratigraphic thickening (Fig 4B; cf. Dixon et al.., 2012b). Thus, Locations 4 to 7, associated with a basinward-dipping profile, represent slope deposits (e.g. Van Wagoner et al., 1990; Pirmez et al., 1998; Plink-Björklund et al., 2001; Glørstad-Clark et al., 2010). The slope is further sub-divided into proximal, medial and distal locations, based on proximity to the clinoform rollover and slope gradient. The most steeply-dipping portion of the clinothem (represented by Location 4), is therefore interpreted as the proximal slope; the medial slope is represented by Locations 5 and 6 , and is associated with a minor gradient-decrease; the distal slope (represented by Location 7) is associated with a further gradient decrease (e.g. Steel \& Olsen, 2002; Glørstad-Clark et al., 2010; Anell \& Midtkandal, 2015). This clinoform geometry interpretation is supported by the distribution of facies, as outlined below.

\section{FACIES ASSOCIATIONS AND DISTRIBUTION}

Five facies associations have been determined within Cycle LG-1, which are distinguishable by differences in sedimentary structure, bed-scale architecture, bed geometry and quantitative differences in grain size and sorting.

\section{Shelf Deposits}

\section{Facies Association A: fluvial channel-fill deposits}

Description (see Table 1)

Facies Association A (FA A) is predominantly composed of fine-grained and medium-grained sandstone ( $34 \%$ and $31 \%$, respectively, Fig. $5 \mathrm{~A}$ ) with a mean grain size of $0.34 \mathrm{~mm}$ (medium-grained sand; Fig. 6A). This FA has a large intra-facies grain-size variability, and can be locally very coarsegrained, although it is generally moderately well-sorted ( $1.50 \sigma$ mean sorting; Fig. 6B). Typically, grains are subangular to rounded. FA A varies from 0.25 to $18.0 \mathrm{~m}$ in thickness (Fig. 7), and has a highly discontinuous, lenticular geometry (Fig. 8A). The base of FA A is erosional, cutting up to $0.5 \mathrm{~m}$ deep into underlying siltstones (Fig. 8B). The base of FA A is often associated with mudstone rip-up clasts. Facies Association A typically shows a fining-upward trend and is bounded by flat to concaveup surfaces. Sedimentary structures include planar and trough cross-stratification; rare asymmetrical current ripple cross-lamination is observed. Typically, cross-strata sets are 0.5 to $1.0 \mathrm{~m}$ thick, and dip uniformly; sets are bounded by flat surfaces, which dip in the same direction as the cross-beds (Fig. $8 C$ ). Sandstones can contain sub-rounded granules and pebbles ( 20 to $50 \mathrm{~mm}$ in size) of extraformational origin concentrated at the base of FA A, or parallel to stratification, which are dominantly quartz, with subordinate feldspar and lithic clasts (Fig. 8D). Locally, plant matter is

This article is protected by copyright. All rights reserved. 
present as detritus. Disarticulated and fragmented bivalve shells form a hash that is found as scourfill. Facies Association A crops out in Locations 1 and 2, stratigraphically thickening towards Location 2 (Figs 4 and 7).

\section{Interpretation}

The presence of lenticular sand bodies, bounded by basal erosion surfaces and containing decimetre-scale cross-bedding with dominant unidirectional palaeocurrents indicates a channel-fill environment for FA A (Farrell, 1987; Collinson et al., 2006); the fluvial nature of the infill is further supported by the presence of terrestrial plant fragments and detritus. The bivalve hash is interpreted to be reworked from underlying deposits. The planar and trough cross-stratified sedimentary structures record the migration of dune-scale bedforms, and the occurrence of basal granules and pebbles indicates relative high-energy conditions. The fining-upward trends suggest progressive flow velocity decrease during the channel infill (e.g. Williams \& Rust, 1969; Bridge et al., 1986). The channel-fill interpretation is further supported by the location of FA A within the geometric shelf-environment.

\section{Facies Association B: delta top overbank deposits}

Description (see Table 1)

Facies Association B (FA B) is predominantly composed of very fine and fine-grained sandstone $(54 \%$ and $32 \%$, respectively, Fig. 5B), and has a mean grain size of $0.10 \mathrm{~mm}$ (very fine-grained sand; Fig. $6 \mathrm{~A})$. This FA is moderately sorted (1.73 $\sigma$ mean sorting; Fig. 6B), with subrounded grains. Bedsets are 1 to $2 \mathrm{~m}$ thick, and composed of 0.05 to $0.1 \mathrm{~m}$ thick and relatively tabular sandstone beds, interbedded with thin ( 0.05 to $0.2 \mathrm{~m}$ thickness) structureless siltstones (Fig. 8E). The sandstone and siltstone units are found interbedded with organic-rich mudstones ( 0.2 to $1.0 \mathrm{~m}$ thick). Tabular sandstone beds have sharp bases and are parallel-laminated (Fig. 8E), passing upward into very finegrained ripple-bedded tops. Facies Association B contains finely comminuted plant detritus. Facies Association B crops out only in Location 1 and thins towards Location 2 (Figs 4 and 7).

\section{Interpretation}

Facies Association B was deposited by low velocity, unidirectional currents. The planar and current ripple lamination and siltstone interbeds indicate changes in velocity and sediment load. The finegrained nature of FA B and the sharp bases of the sandstone elements may support an interpretation as crevasse splay deposits (Ethridge et al., 1981; Gersib \& McCabe, 1981; Bridge,

This article is protected by copyright. All rights reserved. 
1984) or crevasse subdeltas (Gugliotta et al., 2015). The presence of organic-rich mudstones interbedded with the sandstone and siltstone elements represent a local hiatus in crevasse splay deposition (e.g. Slingerland \& Smith, 2004). No definitive terrestrial indicators, such as rootlets or palaeosols are observed in $F A B$, which may suggest that FA B represents subaqueous overbank deposition, perhaps in interdistributary bay areas (e.g. Elliott, 1974). However, the topset deposits of underlying clinothem units (for example, Cycle 2 of the Comaron Composite Sequence, see Dreyer et al., 1999), contain reddened floodplain palaeosols (Labourdette \& Jones, 2007). A subaerial/subaqueous overbank interpretation is strengthened by the location of FA B within the geometric shelf-environment, suggesting a lower delta-plain environment.

\section{Slope Deposits}

\section{Facies Association C: very fine-grained clean turbidites}

\section{Description (see Table 1)}

Facies Association C (FA C) is predominantly composed of very fine-grained and fine-grained sandstone (44\% and 47\%, respectively, Fig. 7C) and has a mean grain size of $0.12 \mathrm{~mm}$ (very finegrained sand; Fig. 6A). This FA is moderately well sorted (1.51 $\sigma$ mean sorting; Fig. 6B). Grains are rounded to well-rounded and predominantly quartz. Facies Association C varies in thickness from 0.5 to $10.0 \mathrm{~m}$, and individual beds are 0.05 to $0.4 \mathrm{~m}$ thick with a tabular appearance (Fig. 9A). Typically, bed bases are flat (Fig. 9A), although some are erosional, cutting up to $0.2 \mathrm{~m}$ deep into underlying siltstones. Typically, beds are ungraded, with local weak normal grading. The dominant sedimentary structures are current-ripple and plane-parallel lamination. Facies Association C has a 'clean' appearance, lacks observable plant detritus or organic matter, and is mica-poor (Fig. 9A). The very fine-grained sandstone beds are interbedded with bioclastic sandstone beds ( 0.5 to $2.0 \mathrm{~m}$ thick) dominated by Nummulites (Fig. 9B to D) (see Mateu-Vicens et al., 2012). In Location 2 (Figs 4 and 7), bioclastic sandstones are dominantly structureless (Fig. 9B), but in Locations 3 to 6 (Figs 4 and 7) they are normally graded (Fig. 9C); foraminifera are also found aligned parallel to internal laminations (Fig. 9D). Basinward, the mean grain-size of FA C varies slightly from $0.084 \mathrm{~mm}$ (very fine-grained sand) in Location 2, to $0.10 \mathrm{~mm}$ (very fine-grained sand) in Location 6 (Fig. 10A). Sorting shows an overall basinward decrease from $1.26 \sigma$ (very well sorted) in Location 2, to $1.59 \sigma$ (moderately well sorted) and $1.52 \sigma$ (moderately well sorted) in Locations 5 and 6 , respectively (Fig. 10B). Facies Association C crops out from Location 2 to Location 6 (Fig. 7), showing an overall basinward-thinning. Facies Association C pinches out and terminates at Location 6, and shows no obvious vertical stratigraphic thickening or thinning trend.

This article is protected by copyright. All rights reserved. 
Interpretation

The presence of both flat and erosive bed bases and abundant traction structures (including planeparallel and current-ripple lamination) is consistent with deposition by turbidity currents (e.g. Lowe, 1982; Mutti et al., 2003; Hiscott et al., 1997; Plink-Björklund et al., 2001). The turbiditic nature of FA $C$ is supported by its deposition on the geometric slope. The significant basinward thinning of FA C suggests deposition by gradual aggradation from decelerating turbidity currents (Kneller, 1995). The normal grading observed in FA C is also characteristic of waning turbidity currents (Bouma 1962, Walker 1967, Lowe 1982, Middleton 1993, Kneller 1995), which are deposited from transient, surgetype turbidity currents that progressively lose sediment carrying-capacity downslope (Lowe 1982, Hiscott 1994, Kneller \& Branney 1995). These turbidites would be expected to show a basinwardfining trend (e.g. Lowe, 1982; Kneller, 1995; Mutti et al., 1999). However, the grain size of FA C shows minimal basinward change $(<0.016 \mathrm{~mm})$ from the zone of the clinoform rollover (Location 2) to the medial slope (Location 6) (Fig. 10A); this almost constant grain-size profile may reflect the original narrow grain-size range available for remobilization and basinward transport. The 'clean' appearance of FA C (i.e. its negligible mica and terrestrial organic matter content), in combination with its high textural maturity (i.e. FA C is very fine-grained, well-sorted, well-rounded and quartzrich) suggests sediment remobilization from a wave-dominated shallow marine shelf deposit (e.g. Cosgrove et al., 2018). This is supported by the direct correlation of outer shelf to shelf-edge (Location 2) structureless foraminifera-bearing bioclastic sandstones with normally-graded bioclastic sandstones in the proximal and medial slope (Locations 3 to 6 ) (Figs 4 and 7). The structureless bioclastic sandstones represent in situ wave-dominated shallow-marine shelf deposits (MateuVicens et al., 2012) and their basinward-equivalent, normally-graded bioclastic sandstones suggest the reworking and basinward transport of foraminifera-rich sands from the contemporaneous shelf.

\section{Facies Association D: fine-grained micaceous turbidites}

\section{Description (see Table 1)}

Facies Association D (FA D) is predominantly composed of very fine-grained and fine-grained sandstone ( $45 \%$ and $43 \%$, respectively, Fig. 5D) with a mean grain size of $0.12 \mathrm{~mm}$ (very fine-grained sand; Fig. 6A). This FA is moderately well sorted (1.50 $\sigma$ mean sorting; Fig. 6B). Facies Association D varies in thickness from 1.75 to $10.0 \mathrm{~m}$ (Fig. 7); individual beds are typically 0.4 to $2.5 \mathrm{~m}$ thick (Fig. $11 \mathrm{~A}$ ) and interbedded with $0.25 \mathrm{~m}$ thick siltstone beds (Fig. 11B). Typically, the base of FA D is erosional and contains abundant rip-up clasts (Fig. 11C). The FA D deposits typically thin and fine upward. Beds show normal, inverse and inverse to normal grading, and can be structureless, but

This article is protected by copyright. All rights reserved. 
most commonly display traction structures, including plane-parallel and current-ripple lamination (Fig. 11D). Facies Association D has a 'dirty' appearance, i.e. it has a high observable mica-content and contains finely comminuted plant detritus. Basinward, grain size shows a prominent fining trend, with mean grain diameter decreasing from $0.34 \mathrm{~mm}$ (medium-grained sand; Location 2) to $0.10 \mathrm{~mm}$ (very fine-grained sand; Location 7) (Fig. 10A). Sorting shows an overall downdip decrease from 1.35 $\sigma$ (well-sorted; Location 2) to $1.5 \sigma$ (moderately well sorted; Location 7) (Fig. 10B). Facies Association D crops out from Location 2 to Location 7 (Figs 4 and 7). At Location 2, FA D can be correlated updip to the fluvial channel-fill associated with FA A. Facies Association D shows a marked basinward thinning trend (Fig. 7) and is commonly interbedded with FA C throughout the study area. Stratigraphically, FA D tends to thicken up-section.

\section{Interpretation}

The erosive bases of FA D, with aligned mudstone clasts and abundance of traction structures (including plane-parallel and current-ripple laminations) support an interpretation of deposition by turbidity currents (e.g. Lowe, 1982; Mutti et al., 2003; Hiscott et al., 1997; Plink-Björklund et al., 2001). The turbiditic nature of FA D is supported by its deposition on the geometric slope. The thick beds (up to $2.5 \mathrm{~m}$ ) with traction structures are indicative of deposition from sustained turbidity currents, through gradual aggradation (Kneller, 1995). The significant thickness of individual turbidites may be indicative of deposition via hyperpycnal flows (e.g. Piper \& Savoye, 1993; Mulder et al., 1998; Kneller \& Buckee; 2000, Mulder \& Alexander; 2001; Plink-Björklund \& Steel; 2004), as river discharge can be sustained at a quasi-constant rate for hours, days or weeks (e.g. Wright et al., 1986; Hay, 1987; Prior et al., 1987; Wright et al., 1988; Nemec, 1990; Wright et al., 1990; Chikita, 1990; Zeng et al., 1991; Mulder et al., 1998; Piper et al., 1999). However, bed thickness cannot be used as a diagnostic criterion alone, as sustained flows can be triggered by various other mechanisms than river discharge (including volcanic eruptions, seismic activity and storm surges).

The physical connection from fluvial channel-fill (FA A) into slope deposits (FA D) suggests that the fluvial feeder system was directly depositing sediment onto the slope (e.g. Steel et al., 2000; PlinkBjörklund et al., 2001; Plink-Björklund \& Steel, 2002; Mellere et al., 2002; Plink-Björklund \& Steel, 2004); this supports an interpretation of river-discharge-generated hyperpycnal flows that deposited their sediment load across the proximal to distal slope.

The presence of high amounts of plant debris and mica within FA D also supports a direct linkage between the fluvial and marine depositional environment (e.g. Mulder et al., 2003; Mutti et al., 2003; Plink-Björklund \& Steel, 2004; Lamb et al., 2008; Zavala \& Arcuri, 2016). Terrestrial organic

This article is protected by copyright. All rights reserved. 
matter and high concentrations of mica are widely used as indicators of hyperpycnal flows (e.g. Normark \& Piper, 1991; Mulder \& Syvitski, 1995; Mulder et al., 2003; Plink-Björklund \& Steel, 2004; Zavala et al., 2011, 2012; Hodgson et al., 2018), associated with sustained river-derived flows during periods of high river discharge.

The basinward thinning and fining of FA D also supports deposition via hyperpycnal flows. As discussed in Plink-Björklund \& Steel (2004), following flood termination coarser grain-size fractions are progressively deposited in a landward direction, and finer grain-size fractions are progressively deposited in a basinward direction, as flow velocity and sediment concentration decrease.

Repeated transitions between inverse and normal grading at intra-bed-scale, suggests the presence of accelerating (waxing) and decelerating (waning) flow regimes (cf. Kneller, 1995). As hyperpycnal flow beds are suggested to record variations in the flood hydrograph (e.g. Mulder \& Alexander, 2001), the waxing episode of river-mouth discharge deposits an inversely graded division and a waning episode deposits a normally graded division, although these trends will not be present across an entire deposit (Mulder et al., 2001). However, inverse and normal grading at bed-scale may also reflect autogenic process, such as fluctuations in plunge-point position, which shred river discharge signals (Lamb et al., 2008, 2010).

\section{Facies Association E: medium-grained, deformed turbidites}

Description (see Table 1)

Facies Association E (FA E) is predominantly composed of medium-grained and coarse-grained sandstone (33\% and $31 \%$, respectively, Fig. $5 \mathrm{E}$ ) and has a mean grain size of $0.39 \mathrm{~mm}$ (mediumgrained sand; Fig. 6A). This FA is moderately well-sorted (1.43 $\sigma$ mean sorting; Fig. 6B). Facies Association E varies in thickness from 0.5 to $10.0 \mathrm{~m}$; individual beds are 0.5 to $6.0 \mathrm{~m}$ thick (Fig. 12A). Bed-bases are commonly sharp and flat. However, erosional bed-bases are observed, cutting up to $0.3 \mathrm{~m}$ deep into underlying siltstone deposits; these surfaces are overlain directly by beds containing mudstone rip-up clasts. Beds show normal and inverse grading or may be ungraded. Facies Association E also shows extensive folding and 'ball and pillow' structures (Fig. 12B and C). Where deformation is less intense primary sedimentary structures are preserved including trough crossstratification (Fig. 12D), parallel and ripple lamination and abundant internal amalgamation surfaces. Facies Association A has a 'dirty' appearance, and contains abundant finely comminuted plant detritus and is highly micaceous. Facies Association E exhibits a basinward coarsening trend from Locations 3 to 6 (Fig. 10A), where grain size increases from $0.33 \mathrm{~mm}$ (medium-grained sand) to 0.45 $\mathrm{mm}$ (medium grained sand); at Location 7, grain-size decreases to 0.31 (medium-grained sand). The

This article is protected by copyright. All rights reserved. 
basinward sorting trend of FA E across the sampled profile shows an initial increase from $1.5 \sigma$ (moderately well-sorted) to $1.3 \sigma$ (well-sorted) at Locations 3 and 4, respectively, and then decreases to $1.44 \sigma$ (moderately well-sorted) in Locations 6 and 7 (Fig. 10b). FA E crops out from Locations 2 to 7 (Figs 4 and 7) and can either thin in a basinward direction or remain at approximately the same thickness (Fig. 7). At Location 2, FA E cuts into and truncates FA A. Facies Association E is interbedded with FA C and FA D throughout the study area; FA E becomes thicker and more common up-section.

\section{Interpretation}

Erosional bases with aligned mudstone clasts, and the abundance of traction structures (including plane-parallel and ripple lamination) suggest deposition via turbidity currents (e.g. Lowe, 1982; Mutti et al., 2003; Hiscott et al., 1997; Plink-Björklund et al., 2001). The turbiditic nature of FA E is supported by its deposition on the geometric slope. The unidirectional cross-stratification suggests that current velocities were relatively high (Plink-Björklund et al., 2001). Trough cross-stratification is associated with migration of 3D dunes (Plink-Björklund et al., 2001; Stevenson et al., 2015; Hodgson et al., 2018). Similar to FA $D$, the significant thickness of individual turbidites (up to $6 \mathrm{~m}$ thick) may be indicative of deposition via hyperpycnal flows (e.g. Piper \& Savoye, 1993; Mulder et al., 1998; Kneller \& Buckee, 2000; Mulder \& Alexander, 2001; Plink-Björklund \& Steel, 2004; Tinterri, 2007). The presence of abundant terrestrial organic matter and high concentrations of mica might also support the interpretation of these deposits as hyperpycnites (e.g. Normark \& Piper, 1991; Mulder \& Syvitski, 1995; Mulder et al., 2003; Plink-Björklund \& Steel, 2004; Zavala et al., 2011, 2012). Facies Association E shows repeated transitions between inverse and normal grading at bed-scale (similarly to FA D, see above), suggesting the presence of accelerating (waxing) and decelerating (waning) flow regimes (cf. Kneller, 1995).

The folds and extensive contorted units indicate slope-induced deformation or slumping. The rapid deposition of sediment associated with hyperpycnal flows can lead to liquefaction processes, resulting in soft sediment deformation (e.g. Pontén \& Plink-Björklund 2009; Plink-Björklund \& Steel, 2004).

Unlike FA D, FA E deposits cannot be directly correlated updip to coeval fluvial channel-fill deposits (FA A), as FA E deposits start in the clinoform rollover zone (Location 2) and erodes into underlying fluvial channelized facies (FA A) (Fig. 7). This suggests strong bypass of the contemporaneous shelf and the active erosion and entrainment of underlying deposits, which may correspond with individual surges in river discharge (e.g. Talling, 2014). Additionally, the overall basinward-coarsening

This article is protected by copyright. All rights reserved. 
trend and general lack of obvious thinning suggests significant proximal bypass, flow acceleration (cf. Kneller et al., 1995), and preferential sediment deposition in the medial and distal slope setting. The erosive nature of FA E and significant shelf-edge bypass suggests that flow velocity of FA E may have been higher, relative to FA D and supports a more catastrophic input of sediment associated with major river flooding events, rather than the sustained hyperpycnal flows associated with FA D.

\section{Facies F: basinal mudstones}

\section{Description (see Table 1)}

Facies Association F (FA F) is very fine- to fine-grained moderately sorted siltstone and varies significantly in thickness (0.5 m to $14.0 \mathrm{~m})$. Typically, FA F is structureless or parallel-laminated, with 1 to $2 \mathrm{~mm}$ thick laminae. Bioturbation is highly variable in FA F (BI 0 to 4 ; see bioturbation index of Taylor \& Goldring, 1993), but most commonly low (BI 1). Horizontal and vertical burrows are observed ( $60 \mathrm{~mm}$ long; 10 to $40 \mathrm{~mm}$ diameter). Facies Association $\mathrm{F}$ crops out across the complete depositional profile from Locations 1 to 7 (Figs 4 and 7) and becomes thicker in a basinward direction.

Interpretation

Facies Association $\mathrm{F}$ is interpreted to be the background sediment, accumulated mainly as a product of waning downslope-decelerating dilute turbidity currents (Kneller, 1995).

\section{PROCESS-REGIME VARIABILITY}

The distribution of slope facies within Cycle LG-1 shows the stratigraphic alternation between FA C, $F A D$ and FA E. The sedimentary texture and structure of FA D and FAE suggest deposition under river-dominated shelf conditions. This is consistent with the interpretation of Dreyer et al. (1999) who interpreted the Sobrarbe Deltaic Complex overall to record a river-dominated system. However, the 'clean' and texturally mature nature of FA C is suggestive of a wave-dominated shelf processregime. As such, this new dataset documents intra-clinothem process-regime variability, in which river-dominated conditions are episodically punctuated by wave-dominated conditions.

\section{DOWNDIP CHANGES IN GRAIN SIZE AND SORTING}

Grain size and sorting have been averaged for each sampling location to illustrate basin-scale changes in grain character (Figs 13 and 14). The grain-size variability in Cycle LG-1 is shown in Figs 13 and 14A. From Locations 1 to 3, there is a decrease in mean grain size from $0.46 \mathrm{~mm}$ (medium-

This article is protected by copyright. All rights reserved. 
grained sand; Location 1) to $0.21 \mathrm{~mm}$ (fine-grained sand; Location 3; Fig 14A). Location 1 has the highest inter-quartile grain-size variability (Fig. 14A). From Locations 4 to 7, mean grain size varies between sampling locations; mean grain-size is $0.25 \mathrm{~mm}$ (medium-grained sand), $0.10 \mathrm{~mm}$ (very fine-grained sand), $0.21 \mathrm{~mm}$ (fine-grained sand) and $0.18 \mathrm{~mm}$ (fine-grained sand) in Locations 4, 5, 6 and 7, respectively (Fig. 14A). The variation in sorting is illustrated by the box and whisker plots in Fig. 14B; it has a limited range from 1.4 (well-sorted, Location 1) to 1.58 (moderately well-sorted, Location 4), with a weak overall basinward decrease in sorting (Fig. 14B).

\section{DISCUSSION}

\section{Mixed-process clinothem evolution}

All clinothems within the Sobrarbe Deltaic Complex, including Cycle LG-1, have been previously interpreted to be 'river-dominated' (see Dreyer et al., 1999). However, detailed analysis of facies reveals a more complicated stratigraphic evolution of process-regime at an intra-clinothem scale. Changes in shelf process-regime result in prominent internal variability in sedimentary texture and structure across the complete depositional profile.

The documented process-regime change between river-dominated and wave-dominated affects the downdip geometric distribution of sedimentary bodies; in this case, sedimentary packages associated with a river-dominated process-regime (FA D and FA E), are distributed across the complete sampled profile, from the shelf (topset) to the distal slope (foreset). In contrast, sanddominated sedimentary packages associated with a wave-dominated process-regime (FA C), are deposited only in the proximal and medial slope environments. As such, distal slope deposits show prominent stratigraphic variability in grain-size; sand-rich packages are interbedded with $>10 \mathrm{~m}$ siltrich deposits. The termination, and downlap, of the wave-dominated, sand-facies on the medial slope results in the coeval deposition of silt in the lower slope setting. As such, only silt-grade sediment fractions are transported into the distal slope setting under a wave-dominated processregime; intra-clinothem variability in shelf process-regime thus directly influences the architecture and sand-content of downdip deposits. The maximum basinward extent of FA C on the medial slope may reflect the maximum down-slope distance at which turbidity currents associated with coeval wave-dominated process regimes can transport their sand-fraction and illustrates their attenuated coarse-grained sediment transport capacity relative to turbidity currents associated with a riverdominated shelf.

This article is protected by copyright. All rights reserved. 
Many clinothem systems are designated as being river-dominated, wave-dominated or tidedominated (e.g. Dreyer et al., 1999; Pink-Björklund et al., 2001; Plink-Björklund \& Steel, 2002; Deibert et al., 2003; Crabaugh \& Steel, 2004; Plink-Björklund \& Steel, 2004; Johannessen \& Steel, 2005; Petter \& Steel, 2006; Sylvester et al., 2012; Ryan et al., 2015). The use of end-member descriptors (i.e. river-dominated, wave-dominated or tide-dominated) has led to the underrecognition of mixed-energy clinothem systems in the ancient record (see Ainsworth et al., 2011; Olariu, 2014; Rossi \& Steel, 2016). As such, relatively few ancient clinothems have been interpreted to document spatial and temporal variability in shelf (topset) process-regime (e.g. Ta et al., 2002; Ainsworth et al., 2008; Plink-Björklund, 2008; Carvajal \& Steel, 2009; Vakarelov \& Ainsworth, 2013; Jones et al., 2015; Gomis-Cartesio et al., 2017). Assigning a clinothem with a dominant shelf (topset) process-regime is also associated with discrete sedimentary processes and facies associations, which are used to inform archetypal river-dominated, wave-dominated or tide-dominated clinothem models (e.g. Elliott, 1986; Bhattacharya \& Walker, 1992; Dalrymple, 1992; Walker \& Plint, 1992). A traditional model of a prograding river-dominated clinothem is associated with a broadly coarseningupward grain-size trends in shelf, slope and basin-floor deposits (Bhattacharya \& Walker, 1992; Steel et al., 2008; Carvajal \& Steel, 2009; Dixon et al., 2012b). However, as it is clearly documented in this case, applying an end-member shelf process-regime classification system to clinothem classification systems fails to adequately account for internal vertical and downdip variability in sedimentary texture associated with variability in topset process-regime conditions. This study highlights the internal textural variability of an individual clinothem, using detailed grain characterization, with potential implications for future studies of basin-margin successions. An additional factor to consider is lateral variability in shelf process regime, which will influence the along-strike distribution of facies and their associated grain character and stratigraphic thicknesses on the clinothem slope.

\section{Sediment bypass at the clinoform rollover}

In Cycle LG-1, the clinothem rollover (Locations 2 and 3) marks a prominent zone of grain-size fining (Figs 13 and 14A). Beyond the clinoform rollover zone, there is a basinward coarsening trend (Location 4), suggesting the presence of strongly bypassing flows across the shelf-edge. However, the bypass of coarse-grained sediment varies prominently between facies, according to: (i) the dominant process-regime in operation at the coeval shelf; and (ii) the hyperpycnal flow-style.

Turbidite beds of FA C (associated with wave-dominated shelf process-regime conditions), do not bypass coarse-grained sand downdip (Fig. 10A); in FA C grain size does not vary significantly at the clinoform rollover or along the depositional profile. The uniformity in grain size observed in FA C across the depositional profile reflects the well-sorted sediment source, possibly associated with

This article is protected by copyright. All rights reserved. 
previous reworking and winnowing processes at the shelf-edge under wave-dominated conditions (e.g. Roy et al., 1994; Bowman \& Johnson, 2014; Cosgrove et al., 2018).

Although FA D and FA E are both associated with river-dominated shelf process-regimes, sediment bypass styles beyond the clinoform rollover vary between the two facies. This is attributed to their variable flow-styles. FA D (interpreted to represent sustained hyperpycnal flows) shows a general fining trend beyond the clinoform rollover and does not bypass large volumes of coarse-grained sand into the distal slope setting. The calibre of sand available at the river-mouth is likely to be a dominant factor controlling grain-size uniformity in FA D. Additionally, the lack of shelf incision associated with FA D indicates a low erosion and entrainment capacity, which attenuates the ability of sustained hyperpycnal flow deposits to incorporate coarser-grained sand-fractions from underlying deposits. In contrast, FA E bypasses the shelf setting and deposits coarse-grained sand in the medial and distal slope setting. The high-energy nature of the episodic hyperpycnal flows of FAE promotes bypass of the shelf and clinoform rollover (e.g. Petter \& Steel, 2006), associated with erosion and entrainment of coarser-grained sand from underlying shelf deposits; this is evidenced by the incision of FAE into the underlying shelf deposits of FA A. In FA E, deposition of the coarsest sediment fractions occurs on the proximal and medial slope; at the distal slope there is a decrease in mean grain size, associated with slope-gradient decrease and consequent flow deceleration (Figs 8 and 15).

In addition to influencing grain size across the depositional profile, the hyperpycnal flow type also influences the stratigraphic thicknesses of the resulting deposits. Episodic hyperpycnal flow deposits (FA E) are generally thicker, relative to their sustained hyperpycnal flow counterparts (FA D); this potentially implies that episodic hyperpycnal flows, associated with major flooding events, are able to transport and deposit higher sediment volumes relative to sustained hyperpycnal flows. However, this might seem counter-intuitive, as sustained hyperpycnal flows are likely to last longer and should thus result in greater stratigraphic bed-thicknesses compared to episodic hyperpycnal flows (e.g. Piper \& Savoye; 1993; Mulder et al., 1998; Kneller \& Buckee, 2000; Mulder \& Alexander, 2001; PlinkBjörklund \& Steel, 2004). However, the relative thickness of FA E (episodic) relative to FA D (sustained) may be localized and represent an artefact of sampling along a 2D depositional profile. Additionally, this may imply that some of the sediment volume associated with FA D is bypassed further downslope into the basin-floor environment, which does not crop-out in this locality (Fig. $15)$.

This article is protected by copyright. All rights reserved. 


\section{Allogenic and autogenic process regime variability}

Intra-clinothem process-regime variability may be driven by allogenic or autogenic forcings (e.g. Muto \& Steel, 1997; Muto \& Steel, 2014; Olariu, 2014). The duration of each cycle within the Sobrarbe Deltaic Complex is on the order of hundreds of thousands of years (Dreyer et al., 1999); as such within Cycle LG-1, intra-clinothem process regime variability occurred over timescales of tens of thousands of years. Allogenic variability, associated with small-scale relative sea-level variations, may account for the observed process-regime change in Cycle LG-1; this possibility is supported by the interpretations of Dreyer et al. (1999), who attribute intra-clinothem unconformities in the underlying Comaron composite sequences to high-frequency episodes of forced regression, associated with repeated small-scale tectonic tilting of the basin-floor. Variations in sediment supply rate provide an alternative allogenic cause of intra-clinothem process regime change. The riverdominated facies (FA D and FA E) may potentially be the result of climatically-activated river floods; as such, periods of heightened precipitation would have resulted in enhanced physical and chemical weathering, associated with increased terrestrial run-off (Schmitz, 1987; Peterson, et al., 2000). In contrast, wave-dominated facies (FA C) would be associated with periods of reduced sediment influx, associated with relatively drier climatic conditions. Variations in Eocene orbital cyclicity, related to the precessional (ca 25 kyr period cycles) influence on precipitation patterns (e.g. Berger, 1978; Kutzbach \& Otto-Bliesner, 1982), provide another potential allogenic mechanism of regulating sediment transport over the timescales observed in Cycle LG-1 (cf. Middle Eocene, Ainsa Basin; Cantalejo \& Pickering, 2014).

Alternatively, autogenic processes such as river-channel avulsion, can result in a transient alongstrike shut-down of the direct connectivity between the river-dominated shelf and deep-water system. Immediately downdip of the delta lobe switching and abandonment, a temporary shift to wave-dominated conditions at the shelf-edge may occur. The case for an autogenic cause of process regime variability is strengthened by the apparent rapidity (10 to $20 \mathrm{kyr}$ ) at which alternating riverdominated and wave-dominated conditions are recorded in the stratigraphic record (e.g. Amorosi \& Milli, 2001; Amorosi et al., 2003; 2005; Correggiari et al., 2005; Olariu, 2014).

Both allogenic and autogenic drivers of process regime change are plausible for Cycle LG-1 and are difficult to distinguish in the absence of additional strike-parallel exposure. However, based on the abrupt intra-clinothem facies changes, and the localized preservation of wave-dominated facies (i.e. wave-dominated conditions are not documented at intra-clinothem scales in other minor sequences; Dreyer et al., 1999), autogenic river-avulsion is the favoured mechanism of intra-clinothem process regime variability in this case.

This article is protected by copyright. All rights reserved. 


\section{CONCLUSIONS}

This study integrates quantitative analysis of grain size and sorting with a traditional outcrop-based study of a single topset-to-bottomset clinothem within the Las Gorgas composite sequence of the Eocene Sobrarbe Deltaic Complex. In the oldest clinothem of the Las Gorgas composite sequence (named here Cycle LG-1), five sandstone-dominated facies have been identified, based on sedimentary texture and structure, and bed geometry. The sandstone-dominated facies associations show quantitative differences in grain size and sorting. Slope deposits are dominated by organic-rich and micaceous hyperpycnal flow deposits (Facies Association D and Facies Association E); these are associated with coeval river-dominated topset deposits (Facies Association A and Facies Association B). Two depositional styles are observed in FA D and FA E, related to the nature of the hyperpycnal flooding events: sustained (FA D), versus episodic (FA E). Sustained hyperpycnal flow deposits show direct river connectivity between the outer-shelf and proximal slope and result in the deposition of fine-grained sand across the complete depositional profile. Episodic hyperpycnal flows mostly bypass the clinoform rollover and incise underlying shelf deposits; deposition of medium-grained and coarse-grained sand occurs mostly on the proximal to distal slope. Episodic flows are interpreted to have higher flux rates, and ultimately may transport more sediment into distal slope settings than lower flux rate sustained flows of longer duration.

Hyperpycnal-flow deposits are interbedded with much cleaner (terrestrial organic matter-poor and mica-poor), finer-grained turbidites (FA C), which do not show characteristics consistent with their hyperpycnal counterparts. The clean and relatively fine-grained nature of FA C suggests strong reworking or deposition under a wave-dominated process regime, under which clean shelf-edge sands are remobilized as turbidity currents. The wave-dominated regime deposits are entirely absent from the distal slope. The facies distributions documented in Cycle LG-1 are therefore the result of rapid temporal changes in the dominant process regime, occurring over timescales of tens of thousands of years; these transitions are interpreted to be the result of autogenic variability at an intra-clinothem scale, and mostly associated with river-avulsion processes.

Quantitatively-documented basinward changes in grain size, alongside facies distributions, indicate that coarse-grained sediment bypass at the clinoform rollover varies according to both the dominant process-regime in operation at the shelf-edge (i.e. wave-dominated versus river-dominated) and the flow-style of river-dominated deposits (i.e. sustained versus episodic hyperpycnal flows). In Cycle LG1 , bypass into the deeper-water setting is driven by episodic hyperpycnal flows; sustained hyperpycnal flows and turbidity currents associated with a wave-dominated shelf do not bypass

This article is protected by copyright. All rights reserved. 
coarse-grained sediment downdip. Instead, all grain sizes are deposited across the slope setting, facilitating clinoform progradation. As such, heterogeneity in grain size is documented not only at a process-regime scale, but variability in coarse-grained sand bypass can be introduced based on the dominant flow-style.

This study applies integrated quantitative grain size and sorting data and sedimentology in order understand the evolution of an individual clinothem sequence. This novel dataset highlights hitherto undocumented intra-clinothem variability, which is directly related to changes in the shelf processregime. Updip shelf process-regime is a fundamental factor controlling downdip architecture and sedimentary texture. The outcrop example from Cycle LG-1, also highlights the complexity and heterogeneity of different flow-types, such that flows associated with sustained and episodic hyperpycnal flows also modulate the distribution, calibre and maturity of sediment transported downdip.This novel outcrop-based study of grain character may be used as a predictive reference for subsurface exploration and provides new insights into the evolution of individual clinothem sequences.

\section{ACKNOWLEDGEMENTS}

We would like to thank the John Wyn-Williams and the Leeds Electron Microscopy and Spectroscopy Centre for their assistance with the preparation and imaging of samples, respectively. We would also like to thank the Institute of Applied Geoscience at the University of Leeds for financial assistance, and Grace and Finn Hodgson for assistance with UAV data collection. We thank reviewers Piret PlinkBjörklund and Roberto Tinterri, and Associate Editor Massimiliano Ghinassi for their valuable comments and advice, which have significantly improved this manuscript.

This article is protected by copyright. All rights reserved. 


\section{REFERENCES}

Adams, E.W. and Schlager, W. (2000) Basic types of submarine slope curvature. J. Sed. Res., 70, 814828.

Ainsworth, R.B., Vakarelov, B.K., and Nanson, R.A. (2011) Dynamic spatial and temporal prediction of changes in depositional processes on clastic shorelines: toward improved subsurface uncertainty reduction and management. AAPG Bull., 95, 267-297.

Ainsworth, R. B., Flint, S.S., and Howell, J.A. (2008) Predicting coastal depositional style: Influence of basin morphology and accommodation to sediment supply ratio within a sequence-stratigraphic framework. In: Recent advances in models of shallow-marine stratigraphy (Eds G.J. Hampson, R.J. Steel, P.M. Burgess, R.W. Dalrymple), SEPM Spec. Publ., 90, 237-263.

Amorosi, A. and Milli, S. (2001) Late Quaternary depositional architecture of Po and Tevere river deltas (Italy) and worldwide comparison with coeval deltaic successions. Sed. Geol. 144, 357-375.

Amorosi, A., Centineo, M. C., Colalongo, M. L., Pasini, G., Sarti, G. and Vaiani, S. C. (2003) Facies architecture and latest Pleistocene-Holocene depositional history of the Po Delta (Comacchio area), Italy. J. Geol. 111, 39-56.

Amorosi, A., Centineo, M. C., Colalongo, M. L. and Fiorini, F. (2005) Millennial-scale depositional cycles from the Holocene of the Po Plain, Italy. Mar. Geol., 222, 7-18.

Anell, I. and Midtkandal, I. (2015) The quantifiable clinothem- types, shapes and geometric relationships in the Plio-Pleistocene Giant Foresets Formation, Taranaki Basin, New Zealand. Basin Res. 29, 277-297.

Asquith, D.O. (1970) Depositional topography and major marine environments, Late Cretaceous, Wyoming. AAPG Bul. 54, 1184-1224.

Berger, A. (1978) Long-term variations of caloric insolation resulting from the Earth's orbital parameters. Quatern. Res. 9, 139-167.

Bhattacharya, J.P. (2006), Deltas. In: Facies Models Revisited (Eds R.G. Walker, and H. Posamentier, H.), SEPM Spec. Publ., 84, 237-292.

Bhattacharya, J. P. and Walker, R.G. (1992) Deltas. In: Facies Models; Response to Sea Level Change (Eds R.G. Walker and N.P. James), Geol. Assoc. Can. 157-177 pp.

This article is protected by copyright. All rights reserved. 
Blott, S.J. and Pye, K. (2001) GRADISTAT: a grain-size distribution and statistics package for the analysis of unconsolidated sediments. Earth Surf. Proc. Land. 26, 1237-1248.

Bouma, A.H. (1962) Sedimentology of Some Flysch Deposits: A Graphic Approach to Facies Interpretation. Elsevier, Amsterdam. 168.

Bowman, A.P. and Johnson, H.D. (2014) Storm-dominated shelf-edge delta successions in a high accommodation setting: The palaeo-Orinoco Delta (Mayaro Formation), Columbus Basin, South-East Trinidad. Sedimentology, 61, 792-835.

Bridge, J.S. (1984) Large-scale facies sequences in alluvial overbank environments. J. Sed. Res., 54, 85-170.

Bridge, J. S., Smith, N.D., Trent, F., Gabel, S. L. and Bernstein, P. (1986) Sedimentology and morphology of a low-sinuosity river: Calamus River, Nebraska Sand Hills. Sedimentology, 33, 851870.

Brunet, M.F. (1986) The influence of the Pyrenees on the development of the adjacent basin. Tectonophysics, 129, 343-354.

Cantalejo, B. and Pickering, K.P. (2014) Climate forcing of fine-grained deep-marine systems in an active tectonic setting: Middle Eocene, Ainsa Basin, Spanish Pyrenees. Palaeogeogr. Palaeoclimatol. Palaeoecol., 410, 351-371.

Carvajal, C. and Steel, R. (2006) Thick turbidite successions from supply-dominated shelves during sea-level highstand. Geology, 34, 665-668.

Carvajal, C. and Steel, R. (2009) Shelf-edge architecture and bypass of sand to deep water: influence of shelf-edge processes, sea level and sediment supply. J. Sed. Res., 79, 652-672.

Catuneanu, O., Abreu, V., Bhattacharya, J.P., Blum, M.D., Dalrymple, R.W., Eriksson, P.G., Fielding, C.R., Fisher, W.L., Galloway, W.E., Gibling, M.R., Giles, K.A., Holbrook, K.A., Jordon, J.M., Kendall, R., Macurda, C.G. St., Macurda, C.B., Martinsen, O.J., Miall, A.D., Neal, J.E., Nummendal, D., Pomar, L., Posamentier, H.W., Pratt, B.R., Sarg, J.F., Shanley, K.W., Steel, R.J., Strasser, A. and Tucker, M.E.C. (2009) Towards the standardization of sequence stratigraphy. Earth-Sci. Rev., 92, 1-33.

Chayes, F. (1950) On the bias of grain-size measurements made in thin-section. J. Geol., 58, 156-160.

This article is protected by copyright. All rights reserved. 
Chikita, K. (1990) Sedimentation by river-induced turbidity currents: field measurements and interpretation. Sedimentology, 37, 891-905.

Collinson, J.D., Mountney, N. P. and Thompson, D. B. (2006) Sedimentary Structures. 3rd edn, Terra Publishing, Harpenden, 292 pp.

Correggiari, A., Cattaneo, A. and Trincardi, F. (2005) The modern Po Delta system: lobe switching and asymmetric prodelta growth. Mar. Geol., 222, 49-74.

Cosgrove, G. I., Hodgson, D. M., Poyatos-Moré, M., Mountney, N. P. and McCaffrey, W. D. (2018). Filter or conveyor? Establishing relationships between clinoform rollover trajectory, sedimentary process regime, and grain Character within intrashelf clinothems, Offshore New Jersey, USA. J. Sed. Res., 88, 917-941.

Cosgrove, G.I.E., Hodgson, D.M., M., Mountney, N.P., McCaffrey, W.M.D., 2019, High-resolution correlations of strata within a sand-rich sequence clinothem using grain fabric data, offshore New Jersey, USA. Geosphere, 19, https://doi.org/10.1130/GES02046.1.

Crabaugh, J.P. and Steel, R.J. (2004) Basin-floor fans of the Central Tertiary Basin, Spitsbergen: relationship of basin-floor sand-bodies to prograding clinoforms in a structurally active basin. Geol. Soc. London Spec. Pub., 222, 187-208.

Dalrymple, R.W. (1992) Tidal depositional systems. In: Facies Models: Response to Sea-Level Change (Eds. R.G., Walker and N.P., James). Geol. Assoc. Canada, p. 195-218.

DeFrederico, A. (1981) La sedimentacion de talud en el sector occidental de la cuenca Paleogena de Ainsa, Autonoma de Barcelona, Publicaciones de Geolocationia, 270 pp.

Deibert, J.E., Benda, T., Løseth, T., Schellpeper, M. and Steel, R.J. (2003) Eocene clinoform growth in front of a storm-wave-dominated shelf, Central Basin, Spitsbergen: No significant sand delivery to deepwater area. J. Sed. Res., 23, 546-558.

Dixon, J.F., Steel, R.J. and Olariu, C. (2012a) River-dominated shelf-edge deltas: delivery of sand across the shelf break in the absence of slope incision. Sedimentology, 59, 1133-1157.

Dixon, J.F., Steel, R.J. and Olariu, C. (2012b) Shelf-edge delta regime as a predictor of the deep-water deposition. J. Sed. Res., 82, 681-687.

This article is protected by copyright. All rights reserved. 
Donovan, A. (2003) Depositional topography and sequence development. In: Shelf margin deltas and linked down slope petroleum systems: Global significance and future exploration potential (Eds. H.H. Roberts, N.C. Rosen, R.H. Fillon and J.B. Anderson). GCSSEPM Spec. Publ., 23, 493-522.

Dreyer, T., Corregidor, J., Arbues, P. and Puigdefabregas, C. (1999) Architecture of the tectonically influenced Sobrarbe deltaic complex in the Ainsa Basin, northern Spain. Sed. Geol., 127, 127-169. Elliott, T. (1986) Deltas. In: Sedimentary Environments and Facies (Eds. H.G. Reading), Oxford, U.K., Blackwell Scientific Publications, p. 113-154.

Elliott, T. (1974) Interdistributary bay sequences and their genesis. Sedimentology, 21, 611-622.

Ethridge, F.G., Jackson, T.J. and Youngberg, A.D. (1981) Floodbasin sequence of a fine-grained meander belt subsystem: The coal-bearing Lower Wasatch and Upper Fort Union Formations, Southern Powder River Basin, Wyoming. In: Recent and Ancient Nonmarine Depositional Environments (Eds F.G. Ethridge), SEPM Spec. Publ., 31, 191-209

Farrell, K.M. (1987) Sedimentology and facies architecture of overbank deposits of the Mississippi River, False River region, Louisiana. In: Recent Developments in Fluvial Sedimentology (Eds F.G. Ethridge and R.M. Flores), SEPM Spec. Publ., 39, 111-120.

Fernández, O., Muñoz, J.A., Arbues, P. and Marzo, M. (2004) Three dimensional reconstruction of Geological surfaces: An example of growth strata and turbidite systems from the Ainsa Basin (Pyrenees, Spain). AAPG Bull., 88, 1049-1068.

Galloway, W.E. (1989) Genetic stratigraphic sequences in basin analysis 1: architecture and genesis of flooding-surface bounded depositional units. AAPG Bull., 73, 125-142.

Gammon, P.R., Neville, L.A., Patterson, R.T., Savard, M.M. and Swindles, G.T. (2017) A log-normal spectral analysis of inorganic grain-size distributions from a Canadian boreal lake core: Towards refining depositional process proxy data from high latitude lakes. Sedimentology, 64, 609-630.

Gersib, G.A. and McCabe, P.J. (1981) Continental coal-bearing sediments of the Port Hood Formation (Carboniferous), Cape Linzee, Nova Scotia, Canada. SEPM Spec. Publ., 31, 95-108.

Gilbert, G.K. (1885) The topographic feature of lake shores. U.S. Geol. Surv. Annual Report, 5, 104 108.

This article is protected by copyright. All rights reserved. 
Glørstad-Clark, E., Faleide, J.I., Lundschien, B.A. and Nystuen, J.P. (2010) Triassic seismic sequence stratigraphy and paleogeography of the Western Barents Sea area. Mar. Petrol. Geol., 27, 14481475.

Glørstad-Clark, E., Birkeland, E.P., Nystuen, J.P., Faleide, J.I. and Midtkandal, I. (2011) Triassic platform-margin deltas in the Western Barents Sea. Mar. Petrol. Geol., 28, 1294-1314.

Gomis-Cartesio, L.E., Poyatos-Moré, M., Flint, S.S., Hodgson, D.M., Brunt, R.L. and Wickens, H.D.V. (2017) Anatomy of a mixed-influence shelf edge delta, Karoo Basin, South Africa. In: Sedimentology of Paralic Reservoirs: Recent Advances (Eds G.J. Hampson, A.D. Reynolds, B. Kostic and M.R. Wells). Geol. Soc. London Spec. Publ., 444, 393-418.

Greenman, N.N. (1951) On the bias of grain-size measurements made in thin-section: a discussion. J. Geol., 59, 268-274.

Gugliotta, M., Flint, S.S., Hodgson, D.M. and Veiga, G.D. (2015) Stratigraphic record of riverdominated crevasse subdeltas with tidal influence (Lajas Formation, Argentina). J. Sed. Res., 85, 265284.

Hadler-Jacobsen, F., Johannessen, E.P., Ashton, N., Henriksen, S., Johnson, S.D. and Kristensen, J.B. (2005) Submarine fan morphology and lithology distribution: a predictable function of sediment delivery, gross shelf-to-basin relief, slope gradient and basin topography. In: Petroleum Geology: North-west Europe and Global Perspectives (Eds A.G. Dore, and B.A. Vinin), Proceedings of the $6^{\text {th }}$ Petroleum Geology Conference Geol. Soc. London, 1121-1145.

Hay, A.E. (1987) Turbidity currents and submarine channel formation in Rupert Inlet, British Columbia: The roles of continuous and surge-type flow. J. Geophys. Res. 92, 2883-2900.

Helland-Hansen, W. (1992) Geometry and facies of Tertiary clinothems, Spitsbergen. Sedimentology, 39, 1013-1029.

Helland-Hansen, W. and Hampson, G.J. (2009) Trajectory analysis: concepts and applications. Basin Res., 21, 454-483.

Henriksen, S., Hampson, G.J., Helland-Hansen, W., Johannessen, E.P. and Steel, R.J. (2009) Shelf edge and shoreline trajectories, a dynamic approach to stratigraphic analysis. Basin Res., 21, 445-453.

Hiscott, R.N. (1994) Loss of capacity, not competence, as the fundamental process governing deposition from turbidity currents. J. Sed. Res., 64, 209-214.

This article is protected by copyright. All rights reserved. 
Hiscott, R.N., Pickering, K.T., Bouma, A.H., Hand, B.M., Kneller, B.C., Postma, G. and Soh, W. (1997) Basin-floor fans in the North Sea: sequence stratigraphic models vs. sedimentary Facies: discussion. AAPG Bull., 81, 662-665.

Hodgson, D.M., Browning, J.V., Miller, K.G., Hesselbo, S., Poyatos-Moré, Mountain, G.S. and Proust, J.-N. (2018) Sedimentology, stratigraphic context, and implications of Miocene bottomset deposits, offshore New Jersey. Geosphere, 14, 95-114.

Hubbard, S.M., Fildani, A., Romans, B.W., Covault, J.A. and McHargue, T.R. (2010) High-relief slope clinoform development: insights from outcrop, Magallanes Basin, Chile. J. Sed. Res., 80, 357-375.

Jennette, D.C., Wawrzyniec, T., Fouad, D., Dunlap, D., Munoz, R., Barrera, D., Williams-Rojas, C. and Escamilla-Herra, A. (2003) Traps and turbidite reservoir characteristics from a complex and evolving tectonic setting, Veracrus Basin, southeastern Mexico. AAPG Bull., 87, 1599-1622.

Johannessen, E.P. and Steel, R.J. (2005) Shelf-margin clinoforms and prediction of deepwater sands. Basin Res., 17, 521-550.

Jones, G.E.D., Hodgson, D.M. and Flint, S.S. (2013) Contrast in the process response of stacked clinothems to the shelf-slope rollover. Geosphere, 9, 299-316.

Jones, G.E.D., Hodgson, D.M. and Flint, S.S. (2015) Lateral variability in clinoform trajectory, process regime, and sediment dispersal patterns beyond the shelf-edge roll over in exhumed basin marginscale clinothems. Basin Res., 27, 657-680.

Kellerhals, R., Shaw, J. and Arora, V.K. (1975) On grain size from thin sections. J. Geol., 83, 79-86.

Kneller, B., (1995) Beyond the turbidite paradigm: physical models for deposition of turbidites and their implications for reservoir prediction. In: Characterization of Deep Marine Clastic Systems (Eds. A.J., Hartley and D.J. Prosser), Geol. Soc. Spec. Publ., 94, 31-49.

Kneller, B.C. and Branney, M.J. (1995) Sustained high-density turbidity currents and the deposition of thick ungraded sands. Sedimentology, 42, 607-616.

Kneller, B. and Buckee, C. (2000) The structure and fluid mechanics of turbidity currents: a review of some recent studies and their geological implications. Sedimentology, 47, 62-94.

This article is protected by copyright. All rights reserved. 
Kutzbach, J.E. and Otto-Bliesner, B.L. (1982) The sensitivity of the African-Asian monsoonal climate to orbital parameter changes for 9000 years BP in a low-resolution general circulation model. J. Atmos. Sci., 39, 1177-1188.

Labourdette, R. and Jones, R.R. (2007) Characterization of fluvial architectural elements using a three-dimensional outcrop data set: Escanilla braided system, South-Central Pyrenees, Spain. Geosphere, 3, 422-434.

Lamb, M.P., Myrow, P.M., Lukens, C., Houck, K. and Strauss, J. (2008) Deposits from wave-influenced turbidity currents: Pennsylvanian Minturn Formation, Colorado, USA. J. Sed. Res., 78, 480-498.

Lamb, M.P., McElroy, B., Kopriva, B., Shaw, J. and Mohrig, D. (2010) Linking river-flood dynamics to hyperpycnal-plume deposits: Experiments, theory, and geological implications. GSA Bull., 122, 13891400.

Laugier, F.J. and Plink-Björklund, P. (2016) Defining the shelf edge and the three-dimensional shelf edge to slope facies variability in shelf-edge deltas. Sedimentology, 63, 1280-1320.

Lowe, D.R. (1982) Sediment gravity flows: II. Depositional models with special reference to the deposits of high-density turbidity currents. J. Sed. Petrol., 52, 279-297.

Mateu-Vicens, G., Pomar, L. and Ferràndez-Cañadell, C. (2011) Nummulitic banks in the upper Lutetian 'Buil level', Ainsa Basin, South Central Pyrenean Zone: the impact of internal waves. Sedimentology, 59, 527-552.

Mellere, D., Plink-Björklund, P. and Steel, R. (2002) Anatomy of shelf deltas at the edge of a prograding Eocene shelf margin, Spitsbergen. Sedimentology, 49, 1181-1206.

Middleton, G.V. (1993) Sediment deposition from turbidity currents. Annu. Rev. Earth Planet. Sci., 21, 89-114.

Mitchum, R.M., Vail, P.R. and Thompson, S. (1977) Seismic stratigraphy and global changes in sea level, part 2: the depositional sequence as the basic unit for stratigraphic analysis. In: Seismic Stratigraphy: Applications to Hydrocarbon Exploration (Ed C.E. Payton). AAPG Mem., 26, 53-62.

Muñoz, J.A. (1992) Evolution of a continental collision belt: ECORS-Pyrenees crustal balanced crosssection. In: Thrust Tectonics (Ed K.R. McClay) Chapman and Hall, London, 235-246 pp.

This article is protected by copyright. All rights reserved. 
Muñoz, J.A., Arbues, P. and Serra-Kiel, J. (1998) The Ainsa Basin and the Sobrarbe oblique thrust system: sedimentological and tectonic processes controlling slope and platform sequences deposited synchronously with a submarine emergent thrust system. In: Field Trip Guidebook of the 15th International Sedimentological Congress, Alicante (Eds. A.M. Hevia and A.R. Soria), 213-223.

Mulder, T. and Alexander, J. (2001) The physical character of subaqueous sedimentary density flows and their deposits. Sedimentology, 48, 269-299.

Mulder, T. and Syvitski, J.P.M. (1995) Turbidity current generated at river mouths during exceptional discharges to the world oceans. J. Geol., 103, 285-299.

Mulder, T., Migeon, S., Savoye, B. and Faugéres, J.-C. (2001) Inversely graded turbidite sequences in the deep Mediterranean. A record of deposits from flood-generated turbidity currents? Geo-Mar. Letters, 21, 86-93.

Mulder, T., Syvitski, J.P.M., Migeon, S., Faugéres, J-C. and Savoye, B. (2003) Marine hyperpycnal flows: initiation, behaviour and related deposits. A review. Mar. Petrol. Geol., 20, 861-882.

Mulder, T., Syvitski, J.P.M. and Skene, K.I. (1998) Modeling erosion and deposition by turbidity currents generated at river mouths. J. Sed. Res., 68, 124-137.

Muto, T. and Steel, R.J. (1997) Principles of regression and transgression: the nature of the interplay between accommodation and sediment supply. J. Sed. Res., 67, 994-1000.

Muto, T. and Steel, R.J. (2014) The autostratigraphic view of responses of river deltas to external forcing: Development of the concept. Int. Assoc. Sedimentol. Spec. Publ., 47, 139-148.

Mutti, E., Tinterri, R., Remacha, E., Mavilla, N., Angella, S. and Fava, L. (1999) An Introduction to the analysis of ancient turbidite basins from an outcrop perspective. AAPG Continuing Education Course Note Series, 39, $61 \mathrm{p}$.

Mutti, E., Steffens, G.S., Pirmez, C., Orlando, M. and Roberts, D. (2003) Turbidites: Models and Problems: Mar. Pet. Geol., 20, 523-933.Nemec, W. (1990) Aspects of sediment movement on steep delta slopes. In: Coarse-Grained Deltas (Eds A. Colella and D.B. Prior), Int. Assoc. Sedimentol. Spec. Publ., 10, $29-73$.

Normark, W.R. and Piper, D.J. (1991) Initiation processes and flow evolution of turbidity currents: implications for the depositional record. SEPM Spec. Publ., 46, 207-230.

This article is protected by copyright. All rights reserved. 
Olariu, C. (2014) Autogenic process change in modern deltas: lessons from the ancient. In: From Depositional Systems to Sedimentary Successions on the Norwegian Continental Margin (Eds A.W. Martinius, R. Ravnås, J.A. Howell, R.J. Steel and J.P. Wonham, J.P.). Int. Assoc. Sedimentol. Spec. Publ., 46, 149-166.

Patruno, S., Hampson, G.J. and Jackson C, A-L. (2015) Quantitative characterisation of deltaic and subaqueous clinoforms. Earth Sci. Rev., 142, 79-119.

Patruno, S. and Helland-Hansen, W. (2018) Clinoforms and clinoform systems: Review and dynamic classification scheme for shorelines, subaqueous deltas, shelf edges and continental margins. Earth Sci. Rev., 185, 202-233.

Peterson, L.C., Haug, G.H., Hughen, K.A., Rohl, U. (2000) Rapid changes in the hydrologic cycle of the Tropical Atlantic during the last glacial. Science, 290, 1947-1951.

Petter, A.L. and Steel, R.J. (2006) Hyperpycnal flow variability and slope organization on an Eocene shelf margin, central basin, Spitsbergen. AAPG Bull., 90, 1451-1472.

Pinous, O.V., Levchuck, M.A. and Sahagian, D.L. (2001) Regional synthesis of the productive Neocomian complex of West Siberia: sequence stratigraphic framework. AAPG Bull., 85, 1713-1730.

Piper, D.J.W. and Savoye, B. (1993) Processes of late Quaternary turbidity current flow and deposition on the Var fan, north-west Mediterranean Sea. Sedimentology, 40, 557-582.

Piper, D.J.W., Hiscott, R.N. and Normark, W.R. (1999) Outcrop-scale acoustic facies analysis and latest Quaternary development of Hueneme and Dume submarine fans, offshore California. Sedimentology, 46, 47-78.

Pirmez, C., Pratson, L.F. and Steckler, M.S. (1998) Clinoform development by advection-diffusion of suspended sediment: modeling and comparison to natural systems. J. Geophys. Res., 103, 141-157.

Plink-Björklund, P. (2008) Wave-to-tide process change in a Campanian shoreline complex, Chimney Rock Tongue, Wyoming and Utah. In: Recent Advances in Models of Siliciclastic Shallow-Marine Stratigraphy (Eds G.J. Hampson, R.J. Steel, P.M. Burgess and R.W. Dalrymple), SEPM Spec. Publ., 90, 265-291.

Plink-Björklund, P., Mellere, D. and Steel, R. (2001) Turbidite variability and architecture of sandprone, deep-water slopes: Eocene clinoforms in the Central Basin, Spitsbergen. J. Sed. Res., 71, 895912.

This article is protected by copyright. All rights reserved. 
Plink-Björklund, P. and Steel, R.J. (2002) Perched-delta architecture and the detection of sea level fall and rise in a slope-turbidite accumulation, Eocene Spitsbergen. Geology, 30, 115-118.

Plink-Björklund, P. and Steel, R.J. (2004) Initiation of turbidity currents: outcrop evidence for Eocene hyperpycnal flow turbidites. Sed. Geol., 165, 29-52.

Poblet, J., Muñoz, J.A., Yrave, A. and Serra-Kiel, J. (1998) Quantifying the kinematics of detachment folds using three-dimensional geometry: Application to the Mediano anticline (Pyrenees, Spain). Geol. Soc. Am. Bull., 110, 111-125.

Pontén, A. and Plink-Bjorklund, P. (2009) Process regime changes across a regressive to transgressive turnaround in a shelf-slope basin, Eocene central basin of Spitsbergen. J. Sed. Res., 79, 2-23.

Poyatos-Moré, M., Jones, G.D., Brunt, R.L., Tek, D., Hodgson, D.M. and Flint, S.S. (2019) Clinoform architecture and facies distribution through an erosional to accretionary basin margin transition. Basin Res. In Press: https://doi.org/10.1111/bre.12351

Prior, D.B., Bornhold, B.D, Wiseman Jr., W.J. and Lowe, D.R. (1987) Turbidity current activity in a British Columbia fjord. Science, 237, 581-584.

Puigdefàbregas, C. (1975) La sedimentacion molasica en la Cuenca de Jaca. Monografia del Instituto de Estudios Pirineos, 104, 1-88.

Pyles, D.R. and Slatt, R.M. (2007) Stratigraphic evolution of the Upper Cretaceous Lewis Shale, Southern Wyoming: Applications to understanding shelf to base-of-slope changes in stratigraphic architecture of mud-dominated, progradational depositional systems. In: Atlas of Deepwater Outcrops (Eds T.H. Nilsen, R.D. Shew, G.S. Steffebd, J.R.J. Studlick). AAPG Stud. Geol., 56, 19. Rich, J.L. (1951) Three critical environments of deposition and criteria for recognition of rocks deposited in each of them. Geol. Soc. Am. Bull., 62, 1-20.

Ross, W.C., Watts, D.E. and May, J.A. (1995) Insights from stratigraphic modelling: mud-limited versus sand-limited depositional systems. AAPG Bull., 79, 231-258.

Rossi, V.M. and Steel, R.J. (2016) The role of tidal, wave and river currents in the evolution of mixedenergy deltas: example from the Lajas Formation (Argentina). Sedimentology, 63, 824-864.

This article is protected by copyright. All rights reserved. 
Roy, P.S., Cowell, P.J., Ferland, M.A. and Thom, B.G. (1994) Wave-dominated coasts. In: Coastal Evolution: Late Quaternary Shoreline Morphodynamics (Eds R.W.G. Carter and C.D. Woodroffe), Cambridge, UK, Cambridge University Press, 121 pp.

Schmitz, B. (1987) The $\mathrm{TiO}_{2} / \mathrm{Al}_{2} \mathrm{O}_{3}$ ratio in the Cenozoic Bengal Abyssal Fan sediments and its use as a paleostream indicator. Mar. Geol., 76, 195-206.

Slingerland, R. and Smith, N.D. (2004) River avulsions and their deposits. Ann. Rev. Earth Plan. Sci., 32, 257-285.

St-Onge, G., Mulder, T., Piper, D.J.W., Hillaire-Marcel, C. and Stoner, J.S. (2004) Earthquake and flood-induced turbidites in the Saguenay Fjord (Quebec): a Holocene paleoseismicity record.

Quatern. Sci. Rev., 23, 283-294.

Steel, R.J. and Olsen, T. (2002) Clinoforms, clinoform trajectory and deepwater sands. In: Sequence Stratigraphic Models for Exploration and Production: Evolving Methodology, Emerging Models and Application Histories (Eds J.M. Armentrout, N.C., Rosen) GCS-SEPM Special Publication 22, 367-381.

Steel, R.J., Carvajal, C., Petter, A.L. and Uroza, C. (2008) Shelf and shelf-margin growth in scenarios of rising and falling sea level. In: Recent Advances in Models of Siliciclastic Shallow-Marine Stratigraphy (Ed G.J. Hampson) SEPM Spec. Publ., 90, 47-71.

Steel, R., Mellere, D., Plink-Björklund, P., Crabaugh, J., Deibert, J., Loeseth, T. and Shellpeper, M. (2000) Deltas v rivers on the shelf edge: their relative contributions to the growth of shelf-margins and basin-floor fans (Barremian and Eocene, Spitsbergen). GCSSEPM 20th Ann. Res. Conf. Spec. Publ., $981-1009$.

Stevenson, C., Jackson C. A.-L., Hodgson, D.M., Hubbard, S.M. and Eggenhuisen, J.T. (2015) Deepwater sediment bypass. J. Sed. Res., 87, 1058-1081.

Sumner, E.J., Talling, P.J., Amy, L.A., Wynn, R.B., Stevenson, C.J. and Frenz, M. (2012) Facies architecture of individual basin-plain turbidites: Comparison with existing models and implications for flow processes. Sedimentology, 59, 1850-1887.

Sylvester, Z., Deptuck, M.E., Prather, B.E., Pirmez, C. and O'Byrne, C. (2012), Seismic stratigraphy of a shelf-edge delta and linked submarine channels in the northeastern Gulf of Mexico. In: Application of the Principles of Seismic Geomorphology to Continental-Slope and Base-of-Slope Systems: Case

This article is protected by copyright. All rights reserved. 
Studies from Seafloor and Near-Seafloor Analogues (Eds B.E. Prather, M.E., Deptuck, D. Mohrig, B. Van Hoorn, B. and R.B. Wynn, R.B.). SEPM Spec. Publ., 99, 31-59.

Ta, T.K.O., Nguyen, V.L., Tateishi, M., Kobayashi, I., Saito,Y. and Nakamura, T. (2002) Sediment facies and Late Holocene progradation of the Mekong River Delta in Bentre Province, southern Vietnam: an example of evolution from a tide-dominated to a tide- and wave-dominated delta. Sed. Geol., 152, 313-325.

Talling, P.J. (2014) On the triggers, resulting flow types and frequencies of subaqueous sediment density flows in different settings. Mar. Geol., 352, 155-182.

Taylor, A.M. and Goldring, R. (1993) Description and analysis of bioturbation and ichnofabric. J. Geol. Soc., 150, 141-148.

Tinterri, R. (2007) The Lower Eocene Roda Sandstone (South-Central Pyrenees): An example of a flood-dominated river-delta system in a tectonically controlled basin. Rivista Italiana di Paleontologia e Stratigrafia, 113, 223-255. Vakarelov, B.K. and Ainsworth, R.B. (2013) A hierarchical approach to architectural classification in marginal-marine systems: bridging the gap between sedimentology and sequence stratigraphy. AAPG Bull., 97, 1121-1161.

Van Lunsen, H. (1970) Geology of the Ara-Cinca region, Spanish Pyrenees, province of Huesca: Geologica Utraiectana, 16, 1-119.

Van Wagoner, J.C., Mitchum, R.M. Jr., Campion, K.M. and Rahmanian, V.D. (1990) Siliciclastic sequence stratigraphy in well locations, cores and outcrops: concepts for high-resolution correlation of time and facies. AAPG, Methods Explor., 7, 55.

Vergés, J. and Muñoz, J.A. (1990) Thrust sequences in the southern Central Pyrenees: Bulletin de la Societe Geologique de France, 8, 265-271.

Wadsworth, J.A. (1994) Sedimentology and Sequence Stratigraphy in an Oversteepened Ramp Setting: Sobrarbe Formation, Ainsa Basin, Spanish Pyrenees. Unpublished Ph.D. Thesis, University of Liverpool, p. 195.

Walker, R.G. (1967) Turbidite sedimentary structures and their relationship to proximal and distal depositional environments. J. Sed. Petrol., 37, 25-43.

This article is protected by copyright. All rights reserved. 
Walker, R.G. and Plint, A.G. (1992) Wave- and storm-dominated shallow marine systems. In: Facies Models: Response to Sea-level Change (Eds R.G. Walker and N.P. James). Geol. Assoc. Canada, 219$238 \mathrm{pp}$.

Williams, P.F. and Rust, B.R. (1969) The sedimentology of a braided river. J. Sed. Petrol., 39, 649-679.

Wright, L.D., Yang, Z.-S., Bornhold, B.D., Keller, G.H., Prior, D.B. and Wiseman Jr., W.J. (1986) Hyperpycnal plumes and plume fronts over the Huanghe (Yellow River) delta front. Geo-Mar. Letters, 6, 97-105.

Wright, L.D., Wiseman, W.J., Bornhold, B.D., Prior, D.B., Suhayda, J.N., Keller, G.H., Yang, L.S. and Fan, Y.B. (1988) Marine dispersal and deposition of Yellow River silts by gravity-driven underflows. Nature 332, 629- 632.

Wright, L.D., Wiseman Jr., W.J., Yang, Z.S., Bornhold, B.D., Kneller, B.C., Prior, D.B. and Suhayda, J.N. (1990) Processes of marine dispersal and deposition of suspended silts off the modern mouth of the Huanghe (Yellow) River. Cont. Shelf Res., 10, 1-40.

Zavala, C., M., Arcuri, M. Di Meglio, H., Gamero, D. and Contreras, C. (2011) A genetic facies tract for the analysis of sustained hyperpycnal flow deposits. In: Sediment transfer from shelf to deep waterRevisiting the delivery system (Eds R.M. Slatt and C. Zavala) AAPG Stud. Geol., 61, 31-51.

Zavala, C., Arcuri, M. and Blanco Valiente, L. (2012) The importance of plant remains as diagnostic criteria for the recognition of ancient hyperpycnites. Revue de Paléobiologie, 11, 457-469.

Zavala, C. and Arcuri, M. (2016) Intrabasinal and extrabasinal turbidites: origin and distinctive characteristics. Sed. Geol., 337, 36-54.

Zeng, J., Lowe, D.R., Prior, D.B., Wiseman Jr., W.J. and Bornhold, B.D. (1991) Flow properties of turbidity currents in Bute Inlet, British Columbia. Sedimentology, 38, 975-996.

This article is protected by copyright. All rights reserved. 


\section{TABLE AND FIGURE CAPTIONS}

\section{Table Captions}

Table 1: Descriptions and interpretations of shelf and slope facies associations (Facies Association A to Facies Association F).

\section{Figure Captions}

1. Map showing the location of the Ainsa Basin and the key neighbouring structural features, within the geological setting of the northern-Spanish South Pyrenean Foreland Basin. The dashed box shown in white, located in the Ainsa Basin, illustrates the area of study within the Sobrarbe Deltaic Complex. Line $X-X^{\prime}$ indicates the location of the approximately dipparallel outcrop transect sampled in this investigation. Adapted from Dreyer et al. (1999).

2. Simplified geological map of the study area. Line $X-X^{\prime}$ shows the location of Las Gorgas Cycle 1 (Cycle LG-1), which is the dip-parallel outcrop transect sampled in this investigation. Line A-A' shows a regional dip-parallel cross-section as shown in Fig. 3.

3. Regional cross-section showing the Sobrarbe Deltaic Complex stratigraphy (Line A-A'; Fig. 2). The Sobrarbe Deltaic Complex is comprised of the uppermost part of the San Vicente Formation, the Sobrarbe Formation and up to the middle part of Mondot Member of the Escanilla Formation. The Sobrarbe Formation comprises several composite sequences: Comaron, Las Gorgas, Baranco el Solano and Buil. Highlighted in the burgundy box is line $\mathrm{X}-\mathrm{X}$ ' (see Fig. 4), which is the study site of this investigation (Cycle LG-1). A simplified facies distribution is overlain. Adapted from Dreyer et al. (1999).

4. (A) Outcrop model constructed from unmanned aerial vehicle (UAV) photographs showing the study site (line $X-X^{\prime}$ in Fig. 3); the upper and lower bounding surfaces of Cycle LG-1 are highlighted in yellow. The sedimentary log locations and sampling transects are highlighted in blue and are numbered. (B) Total log thickness at each logging and sampling location.

5. Pie charts illustrating differences in grain-size composition between Facies $A$ to E. Sample numbers for each facies are shown in Fig. 6A. Facies $A=$ fluvial channel-fill deposits; Facies $B$ = delta top overbank deposits; Facies $C=$ very fine-grained clean turbidites; Facies $D=$ finegrained micaceous turbidites; Facies $\mathrm{E}=$ medium-grained, deformed turbidites.

This article is protected by copyright. All rights reserved. 
6. Grain size and sorting for Facies A to E. (A) Box and whisker plot illustrating differences in grain size between Facies A to E. (B) Box and whisker plot illustrating differences in sorting between Facies $A$ to $E$. Sample numbers for each facies are shown are in shown in (A). Facies $A=$ fluvial channel-fill deposits; Facies $B=$ delta top overbank deposits; Facies $C=$ very finegrained clean turbidites; Facies $D=$ fine-grained micaceous turbidites; Facies $E=$ mediumgrained, deformed turbidites.

7. Sedimentary logs showing stratigraphic and dip-parallel facies distributions in Cycle LG-1. The inset shows an enlarged grain-size scale: $c$ = clay; $s$ = silt; $v f=$ very fine-grained sand; $f=$ fine-grained sand; $m$ = medium-grained sand; $c$ = coarse-grained sand; $v c=$ very coarsegrained sand; $g$ = gravel; $b=$ boulders.

8. Representative facies photographs. (A) Lenticular sand-body geometry (Facies Association A -FA A). (B) Close-up of channel-fill within lenticular sand-body (FA A). (C) Trough crossbedding with uniformly dipping foresets (FA A); $0.32 \mathrm{~m}$ hammer for scale. (D) Sub-rounded granules and pebbles of extraformational origin aligned parallel to stratification (FA A); marks on Jacob's Staff denote $10 \mathrm{~cm}$ intervals. (E) Tabular sandstone beds, interbedded with structureless silt (Facies Association B - FA B).

9. Representative facies photographs (Facies Association C - FA C). (A) Tabular beds of planeparallel laminated, very fine-grained, quartz-rich, clean sandstone. (B) Structureless Foraminifera-dominated bioclastic sandstone (found in Location 2; see Figs 4 and 7); lens cap for scale. (C) Normally graded Foraminifera-dominated bioclastic sandstone (found in Locations 3 to 6; see Figs 4 and 7); arrow indicates fining direction. (D) Foraminifera aligned parallel to laminations (found in Locations 3 to 6; see Figs 4 and 7); $50 \mathrm{~mm}$ diameter lens cap for scale.

10. Basinward trends in grain size and sorting for Facies A to E of Cycle LG-1. Sampling locations are illustrated in the numbered boxes. Sample numbers for each facies are shown in Fig. 6A.

11. Representative facies photographs (Facies Association D - FA D). (A) 0.75 to $1.5 \mathrm{~m}$ thick finegrained sandstone beds, note the micaceous appearance; hammer for scale. (B) $0.5 \mathrm{~m}$ thick beds of Facies Association E - FA E, interbedded with $0.25 \mathrm{~m}$ thick siltstone beds. (C) Concave upward bed-base with aligned mudstone rip-up clasts; lens cap for scale $(50 \mathrm{~mm}$ diameter). D) Plane-parallel laminated sandstone.

This article is protected by copyright. All rights reserved. 
12. Representative facies photographs (Facies Association E - FA E). (A) 4 m thick mediumgrained sandstone bed, with erosive base cutting into underlying deposits; human for scale, ca $1.8 \mathrm{~m}$ tall. (B) Contorted units; $1.5 \mathrm{~m}$ Jacob's Staff for scale. (C) Ball and pillow deformation structures; marks on Jacob's Staff denote $10 \mathrm{~cm}$ intervals. (D) Trough crossstratification; $0.2 \mathrm{~m}$ notebook for scale.

13. Grain-size cumulative frequency plot showing basinward changes in grain size at each sampling location.

14. Basinward trends in grain-size and sorting data. (A) Box and whisker plots showing basinward changes in grain size at each sampling location. (B) Box and whisker plots showing basinward changes in sorting at each sampling location.

15. Clinothem model based on Cycle LG-1, including schematic grain-size logs; both grain size and the distribution of sand and mud vary downdip and through the stratigraphy at an intraclinothem scale. Variability occurs according processes operating in the shelf, including the dominant process-regime in operation at the shelf-edge (interpreted to relate to autogenic river avulsion), and the flow style (i.e. sustained versus episodic hyperpycnal flows). Inferred bypass of the sustained hyperpycnal flows (Facies Association D - FA D) further downslope into the deep-water (basin-floor) environment is also illustrated.

This article is protected by copyright. All rights reserved. 


\begin{tabular}{|c|c|c|c|c|c|c|c|c|c|c|c|c|c|}
\hline \multirow[t]{2}{*}{ FA } & \multirow{2}{*}{$\begin{array}{l}\text { Total } \\
\text { thicknes } \\
\mathrm{s}(\mathrm{m})\end{array}$} & \multirow{2}{*}{$\begin{array}{l}\text { Bed } \\
\text { thicknes } \\
s(m)\end{array}$} & \multicolumn{3}{|c|}{ Lithology } & \multirow[t]{2}{*}{ Grading } & \multirow{2}{*}{$\begin{array}{l}\text { Sedimentar } \\
\text { y structures }\end{array}$} & \multirow{2}{*}{$\begin{array}{l}\text { Fossil } \\
\text { content }\end{array}$} & \multirow{2}{*}{$\begin{array}{l}\text { Terrestrial } \\
\text { organic } \\
\text { matter }\end{array}$} & \multirow[t]{2}{*}{$\mathrm{BI}$} & \multirow[t]{2}{*}{ Description } & \multirow[t]{2}{*}{ Geometry } & \multirow[t]{2}{*}{ Interpretation } \\
\hline & & & $\begin{array}{l}\text { Mean } \\
\text { grain } \\
\text { size } \\
(\mathrm{mm})\end{array}$ & $\begin{array}{l}\text { Mean } \\
\text { sorting }(\sigma)\end{array}$ & $\begin{array}{l}\text { Grain } \\
\text { shape }\end{array}$ & & & & & & & & \\
\hline A & $\begin{array}{l}0.25- \\
18\end{array}$ & $0.2-0.6$ & $\begin{array}{l}0.34 \\
\text { (mediu } \\
\mathrm{m}- \\
\text { grained } \\
\text { sand) }\end{array}$ & $\begin{array}{l}1.50 \\
\text { (moderate } \\
\text { ly well } \\
\text { sorted) }\end{array}$ & $\begin{array}{l}\text { Subangula } \\
r \text { to } \\
\text { rounded }\end{array}$ & Normal & $\begin{array}{l}\text { Planar } \\
\text { bedding; } \\
\text { trough } \\
\text { cross- } \\
\text { bedding; } \\
\text { rare } \\
\text { asymmetric } \\
\text { current } \\
\text { ripple } \\
\text { bedding }\end{array}$ & $\begin{array}{l}\text { Rare } \\
\text { disarticulate } \\
d \text { bivalves } \\
\text { found } \\
\text { concentrate } \\
d \text { in scour- } \\
\text { infill }\end{array}$ & $\begin{array}{l}\text { Common as } \\
\text { finely } \\
\text { comminuted } \\
\text { detritus; } \\
\text { rarely as } \\
\text { identifiable } \\
\text { plant } \\
\text { remains }\end{array}$ & $0 / 1$ & $\begin{array}{l}\text { Erosionally based, } \\
\text { fining-upward, medium- } \\
\text { grained sandstone units, } \\
\text { with basal granules and } \\
\text { pebbles and rip-up } \\
\text { clasts }\end{array}$ & $\begin{array}{l}\text { Crops out in } \\
\text { Locations } 1 \text { (shelf) } \\
\text { and } 2 \text { (clinoform } \\
\text { rollover). Lenticular } \\
\text { appearance with } \\
\text { highly variable } \\
\text { stratigraphic } \\
\text { thickness }\end{array}$ & $\begin{array}{l}\text { Fluvial } \\
\text { channel-fill }\end{array}$ \\
\hline$B$ & $1-2$ & $\begin{array}{l}0.05- \\
0.1\end{array}$ & $\begin{array}{l}0.10 \\
\text { (very } \\
\text { fine- } \\
\text { grained } \\
\text { sand) }\end{array}$ & $\begin{array}{l}1.73 \\
\text { (moderate } \\
\text { ly sorted) }\end{array}$ & $\begin{array}{l}\text { Subrounde } \\
\text { d }\end{array}$ & Ungraded & $\begin{array}{l}\text { Parallel } \\
\text { laminations; } \\
\text { ripple- } \\
\text { topped } \\
\text { beds }\end{array}$ & - & $\begin{array}{l}\text { Finely } \\
\text { comminuted } \\
\text { detritus }\end{array}$ & $0 / 1$ & $\begin{array}{l}\text { Sharp to erosionally } \\
\text { based, very fine-grained } \\
\text { sandstone, with parallel } \\
\text { laminations and rippled } \\
\text { bed-tops }\end{array}$ & $\begin{array}{l}\text { Crops out in Location } \\
1 \text { (shelf). Beds are } \\
\text { tabular and sheet- } \\
\text { like }\end{array}$ & $\begin{array}{l}\text { Delta top } \\
\text { overbank } \\
\text { deposits }\end{array}$ \\
\hline C & $0.5-10$ & $\begin{array}{l}0.05- \\
0.4\end{array}$ & $\begin{array}{l}0.12 \\
\text { (very } \\
\text { fine- } \\
\text { grained } \\
\text { sand) }\end{array}$ & $\begin{array}{l}1.51 \\
\text { (moderate } \\
\text { ly well } \\
\text { sorted) }\end{array}$ & $\begin{array}{l}\text { Rounded } \\
\text { to well } \\
\text { rounded }\end{array}$ & $\begin{array}{l}\text { Ungraded } \\
\text { and normal }\end{array}$ & $\begin{array}{l}\text { Plane- } \\
\text { parallel and } \\
\text { current- } \\
\text { ripple } \\
\text { lamination }\end{array}$ & $\begin{array}{l}\text { Foraminifer } \\
\text { a, } \\
\text { gastropods, } \\
\text { bivalves }\end{array}$ & - & 1 & $\begin{array}{l}\text { Sharp based, very fine- } \\
\text { grained sandstone with } \\
\text { 'clean' appearance } \\
\text { (composed } \\
\text { predominantly of quartz } \\
\text { and contains no organic } \\
\text { matter or mica) }\end{array}$ & $\begin{array}{l}\text { Crops out in } \\
\text { Locations } 2 \\
\text { (clinoform rollover } \\
\text { zone) to } 6 \text { (medial } \\
\text { slope). Beds are } \\
\text { tabular. Overall } \\
\text { stratigraphic } \\
\text { thinning downdip }\end{array}$ & $\begin{array}{l}\text { Turbidity } \\
\text { current } \\
\text { deposits, } \\
\text { associated } \\
\text { with } \\
\text { remobilised } \\
\text { sediment from } \\
\text { a wave- } \\
\text { dominated } \\
\text { shelf edge }\end{array}$ \\
\hline $\mathrm{D}$ & $\begin{array}{l}1.75- \\
10\end{array}$ & $0.4-2.5$ & $\begin{array}{l}0.12 \\
\text { (very } \\
\text { fine- } \\
\text { grained } \\
\text { sand) }\end{array}$ & $\begin{array}{l}1.50 \\
\text { (moderate } \\
\text { ly well } \\
\text { sorted) }\end{array}$ & $\begin{array}{l}\text { Subangula } \\
r \text { to } \\
\text { rounded }\end{array}$ & $\begin{array}{l}\text { Normal, } \\
\text { inverse and } \\
\text { inverse to } \\
\text { normal }\end{array}$ & $\begin{array}{l}\text { Structureles } \\
\mathrm{s} \text {, plane- } \\
\text { parallel and } \\
\text { current- } \\
\text { ripple } \\
\text { lamination }\end{array}$ & - & $\begin{array}{l}\text { Finely } \\
\text { comminuted } \\
\text { detritus }\end{array}$ & $1 / 2$ & $\begin{array}{l}\text { Erosionally based, very } \\
\text { fine-grained sandstone } \\
\text { with 'dirty' appearance } \\
\text { (contains abundant } \\
\text { organic matter and } \\
\text { mica). }\end{array}$ & $\begin{array}{l}\text { Crops out in } \\
\text { Locations } 2 \\
\text { (clinoform rollover } \\
\text { zone) to } 7 \text { (distal } \\
\text { slope). Overall } \\
\text { stratigraphic } \\
\text { thinning downdip }\end{array}$ & $\begin{array}{l}\text { Sustained } \\
\text { hyperpycnal } \\
\text { flow } \\
\text { associated } \\
\text { with a river- } \\
\text { dominated } \\
\text { shelf-edge }\end{array}$ \\
\hline
\end{tabular}

This article is protected by copyright. All rights reserved. 


\begin{tabular}{|l|l|l|l|l|l|l|l|l|l|l|l|l|}
\hline E & $0.5-10$ & $0.5-6$ & $\begin{array}{l}0.39 \\
\text { (mediu } \\
\text { m- } \\
\text { grained } \\
\text { sand) }\end{array}$ & $\begin{array}{l}1.43 \\
\text { (moderate } \\
\text { ly well } \\
\text { sorted) }\end{array}$ & $\begin{array}{l}\text { Subangula } \\
\text { rto } \\
\text { rounded }\end{array}$ & $\begin{array}{l}\text { Normal, } \\
\text { inverse and } \\
\text { ungraded }\end{array}$ & - & - & $\begin{array}{l}\text { Finely } \\
\text { comminuted } \\
\text { detritus }\end{array}$ & $\begin{array}{l}\text { 1-3 } \\
\text { Erosionally, or sharp } \\
\text { based, deformed, } \\
\text { medium-grained } \\
\text { sandstone with 'dirty' } \\
\text { appearance (contains } \\
\text { abundant organic } \\
\text { matter and mica) }\end{array}$ & $\begin{array}{l}\text { Crops out in } \\
\text { Locations 2 } \\
\text { (clinoform rollover } \\
\text { zone) to 7 (distal } \\
\text { slope). Beds can } \\
\text { remain at the same } \\
\text { thickness or thin } \\
\text { downdip }\end{array}$ \\
\hline F & $0.5-14$ & - & $\begin{array}{l}\text { Very } \\
\text { fine- } \\
\text { grained } \\
\text { silt }\end{array}$ & - & $\begin{array}{l}\text { Cyperpycnal } \\
\text { associated } \\
\text { with a river- } \\
\text { dominated } \\
\text { shelf-edge } \\
\text { predominantly in } \\
\text { Locations 5 to 7 } \\
\text { (medial to distal } \\
\text { slope) }\end{array}$ & $\begin{array}{l}\text { Dilute } \\
\text { turbidity } \\
\text { currents }\end{array}$ & $\begin{array}{l}\text { Structureles } \\
\text { s, faint } \\
\text { parallel } \\
\text { lamination }\end{array}$ & - & - & - & $0-4$ & $\begin{array}{l}\text { Structureless to faintly } \\
\text { laminated siltstone }\end{array}$ \\
\hline
\end{tabular}

$\mathrm{FA}=$ Facies Association; $\mathrm{BI}=$ Bioturbation Index .

* See Bioturbation Index of Taylor \& Goldring (1 993)

This article is protected by copyright. All rights reserved. 


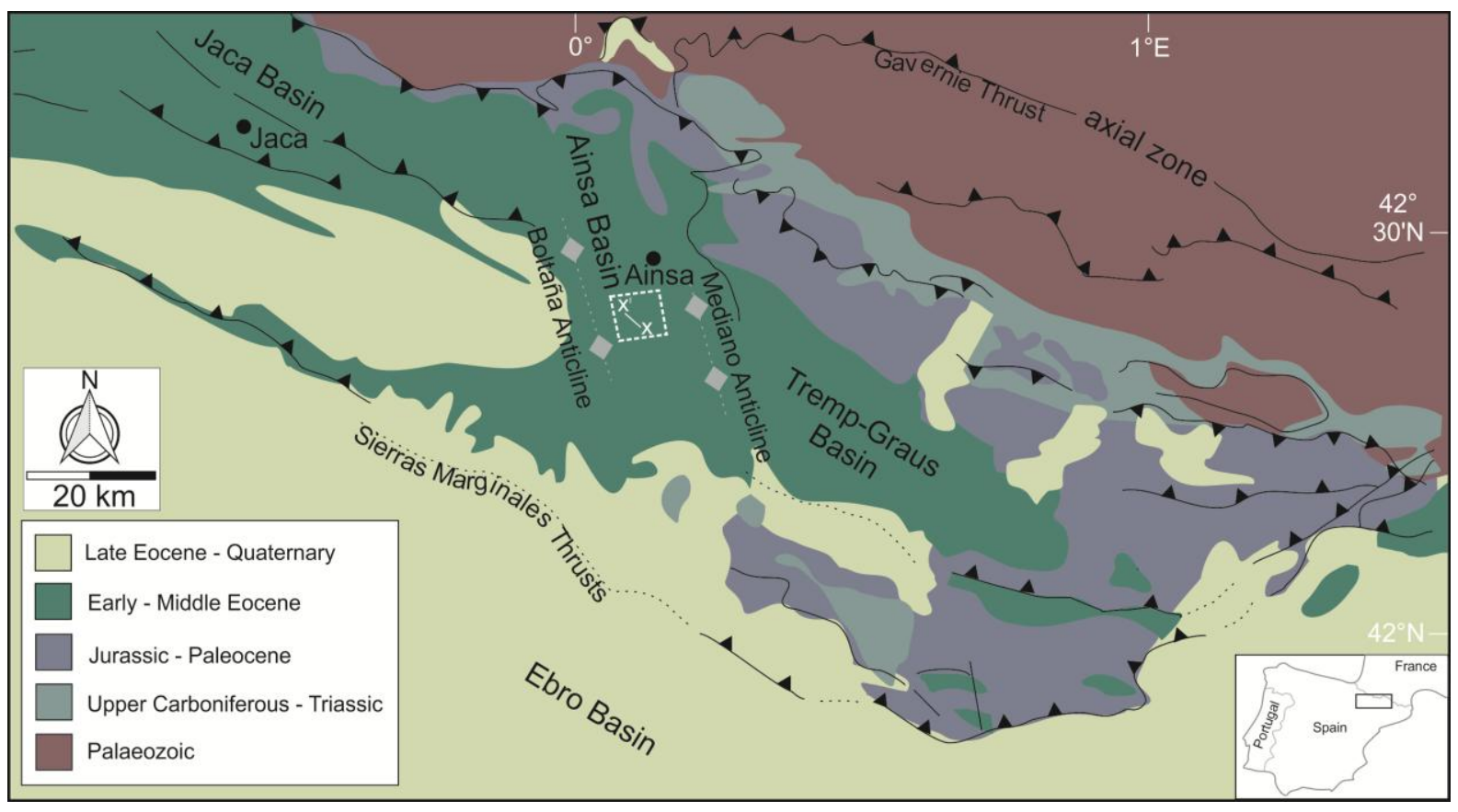

This article is protected by copyright. All rights reserved. 


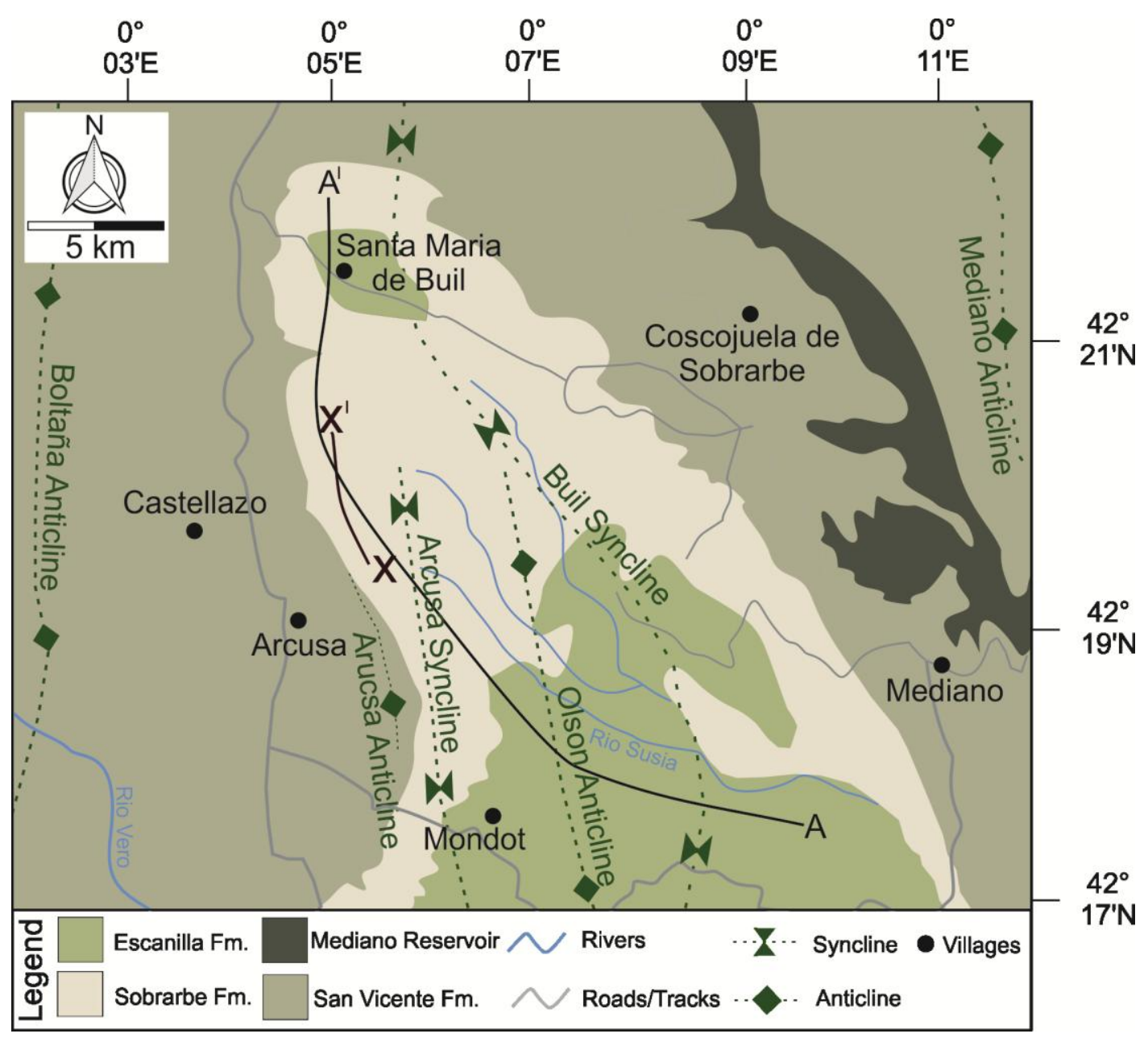

This article is protected by copyright. All rights reserved. 


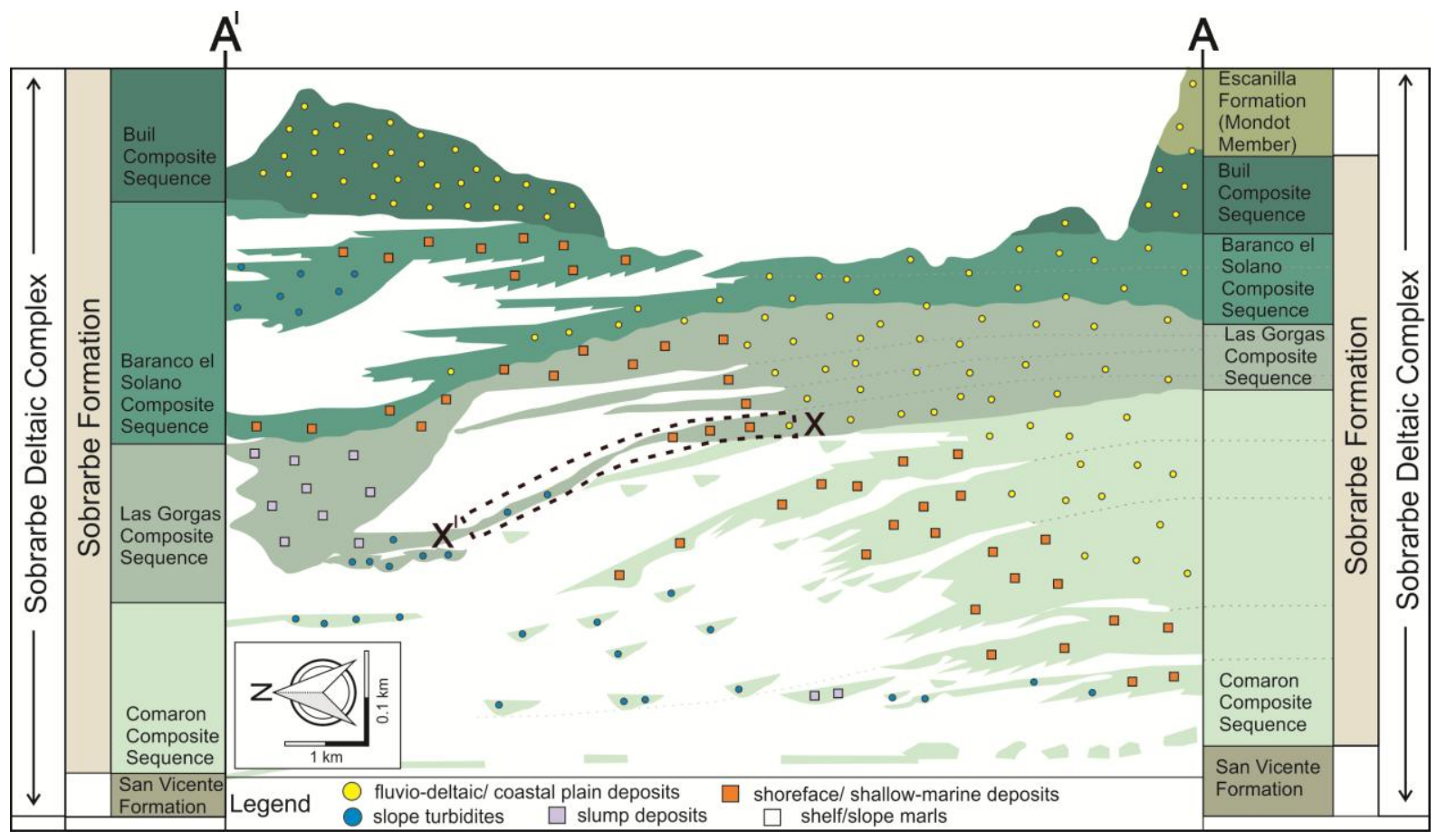

This article is protected by copyright. All rights reserved. 


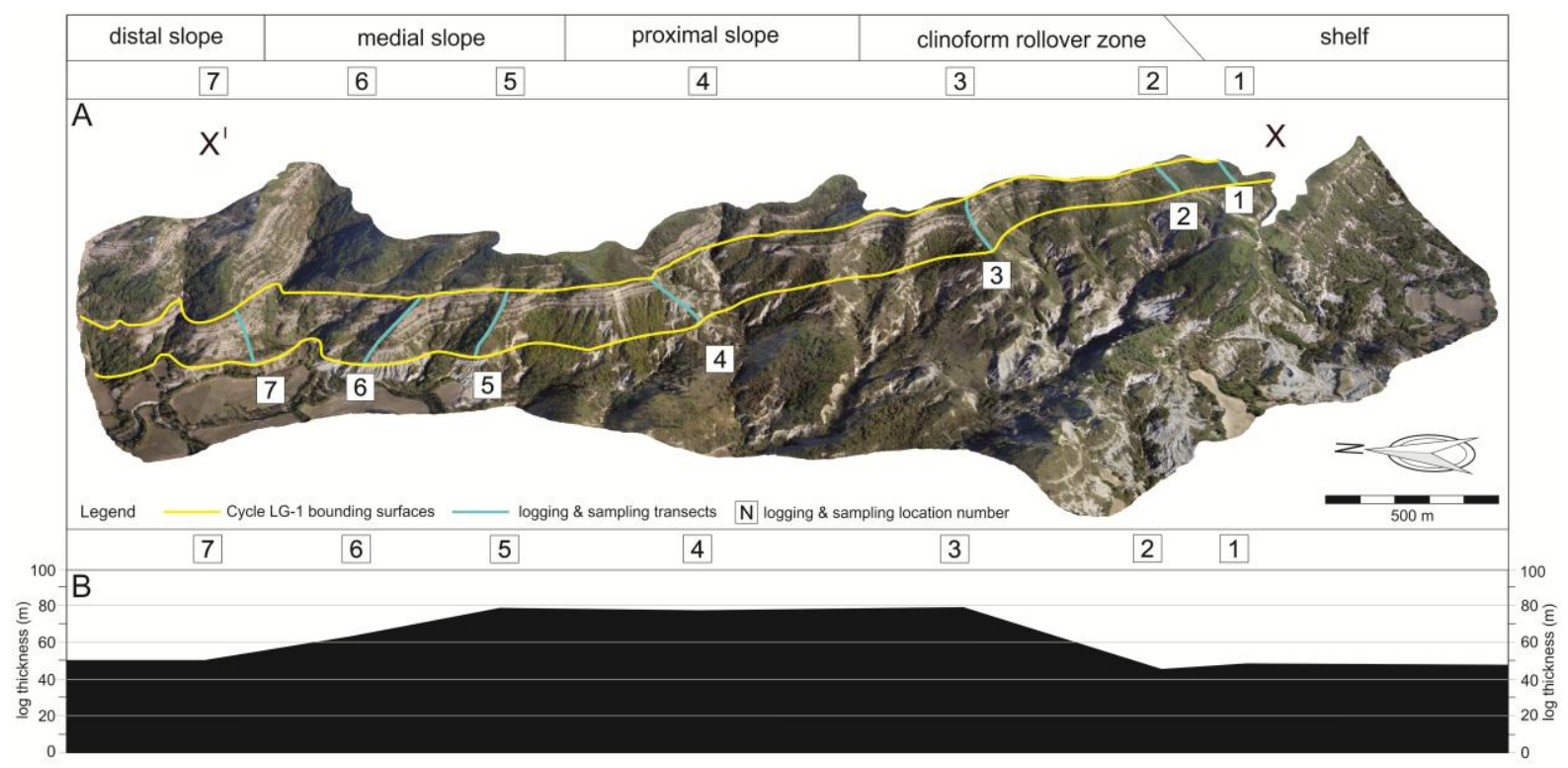

This article is protected by copyright. All rights reserved. 


Legend $\square$ medium sitt $\square$ coarse silt $\square$ very coarse silt $\square$ very fine sand $\square$ fine sand $\square$ medium sand $\square$ coarse sand

This article is protected by copyright. All rights reserved. 


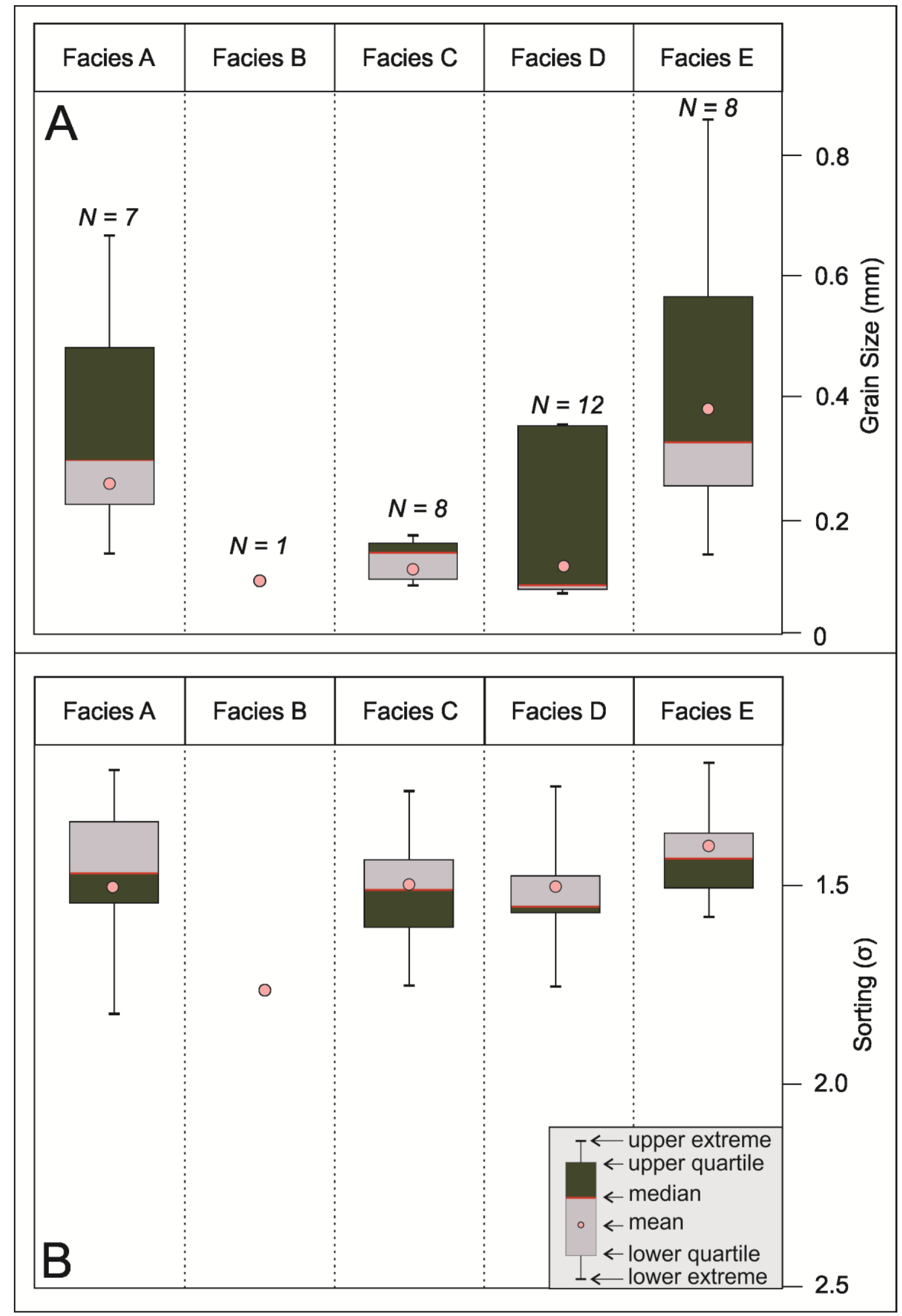

This article is protected by copyright. All rights reserved. 


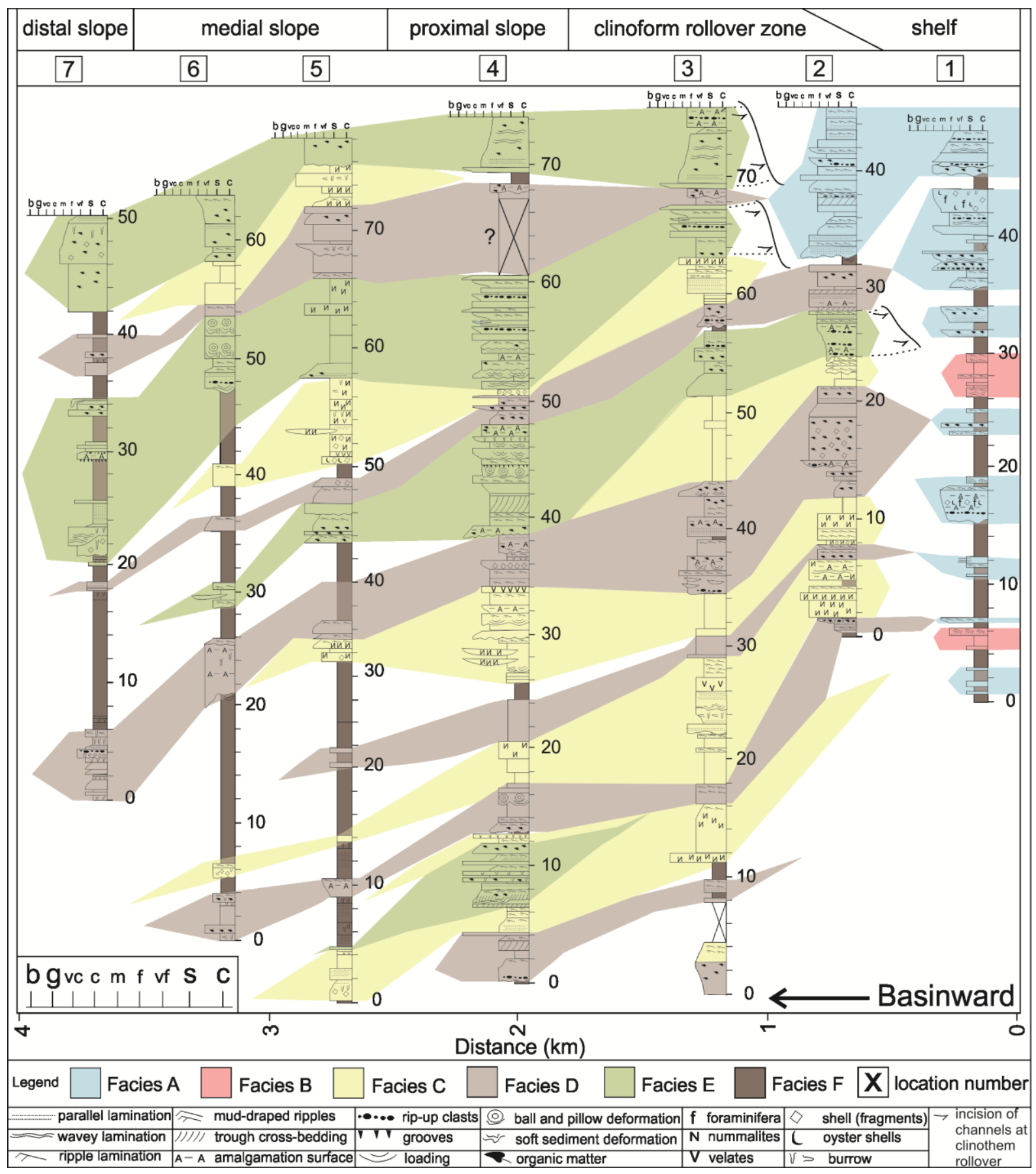

This article is protected by copyright. All rights reserved. 


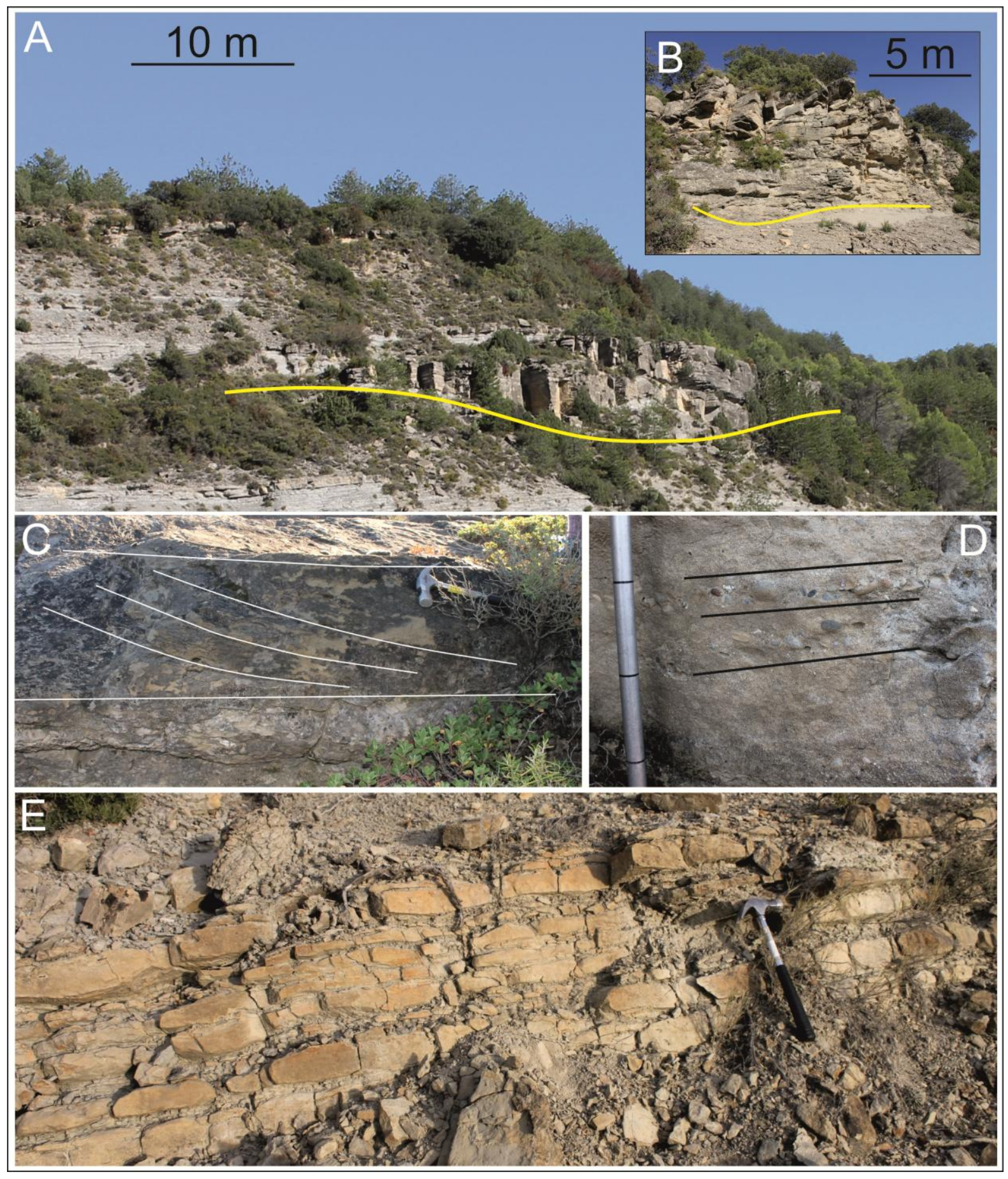

This article is protected by copyright. All rights reserved. 


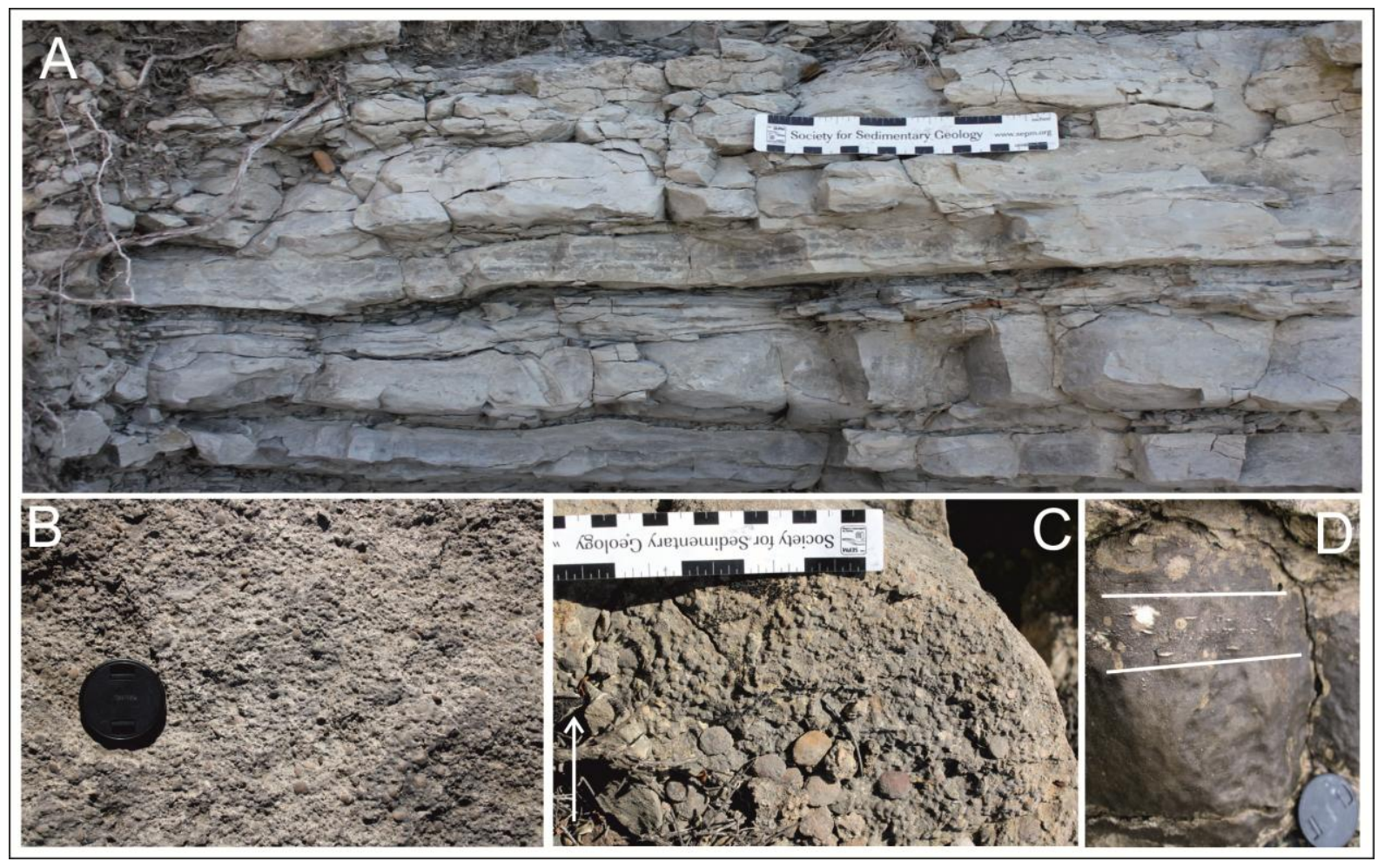

This article is protected by copyright. All rights reserved. 


\begin{tabular}{|c|c|c|c|c|c|c|c|}
\hline distal slope & \multicolumn{2}{|c|}{ medial slope } & proximal slope & \multicolumn{2}{c|}{ clinoform rollover zone } & shelf & \\
\hline 7 & 6 & 5 & 4 & 3 & 2 & 1 \\
\hline \\
\hline
\end{tabular}

This article is protected by copyright. All rights reserved. 


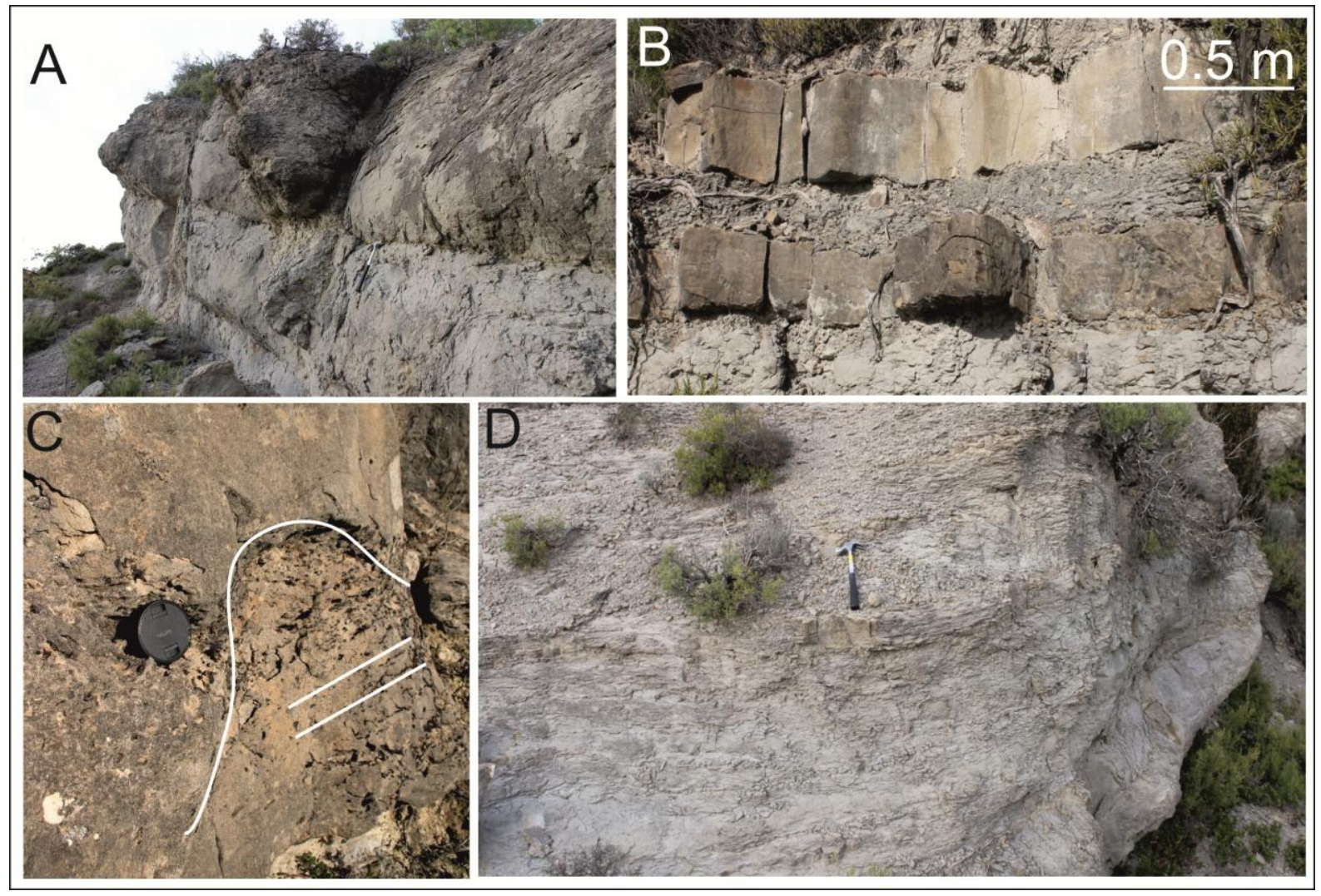

This article is protected by copyright. All rights reserved. 

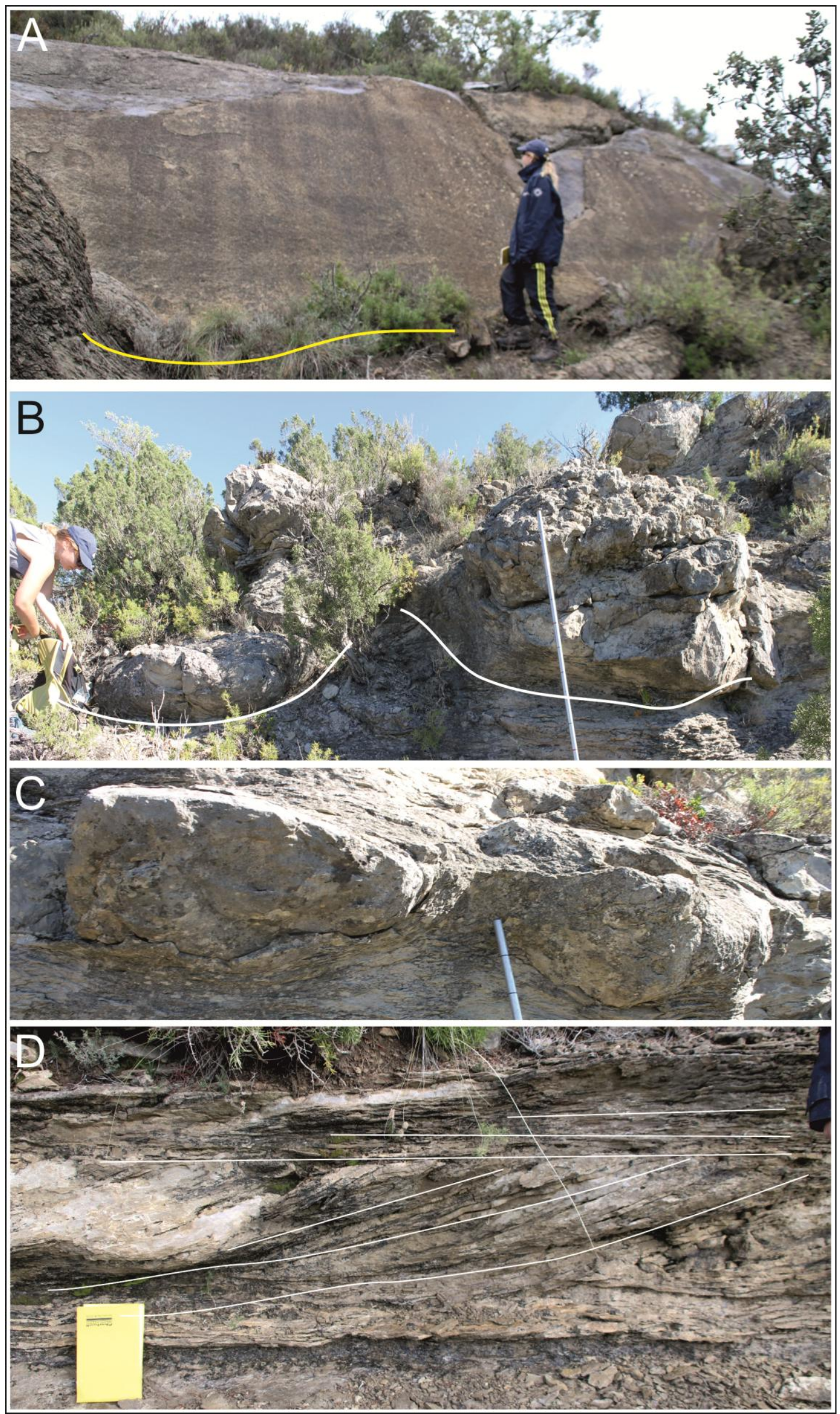

This article is protected by copyright. All rights reserved. 


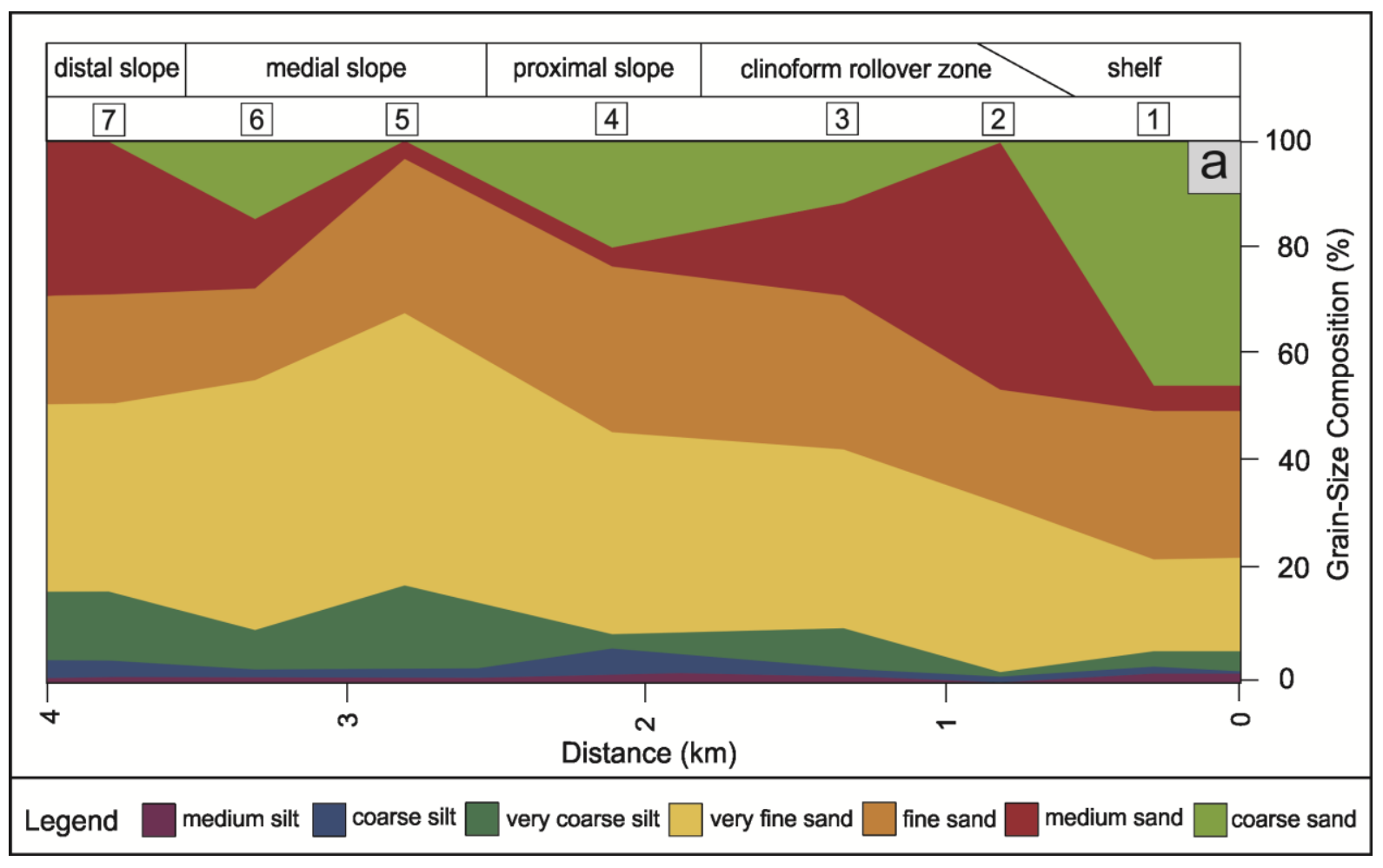

This article is protected by copyright. All rights reserved. 


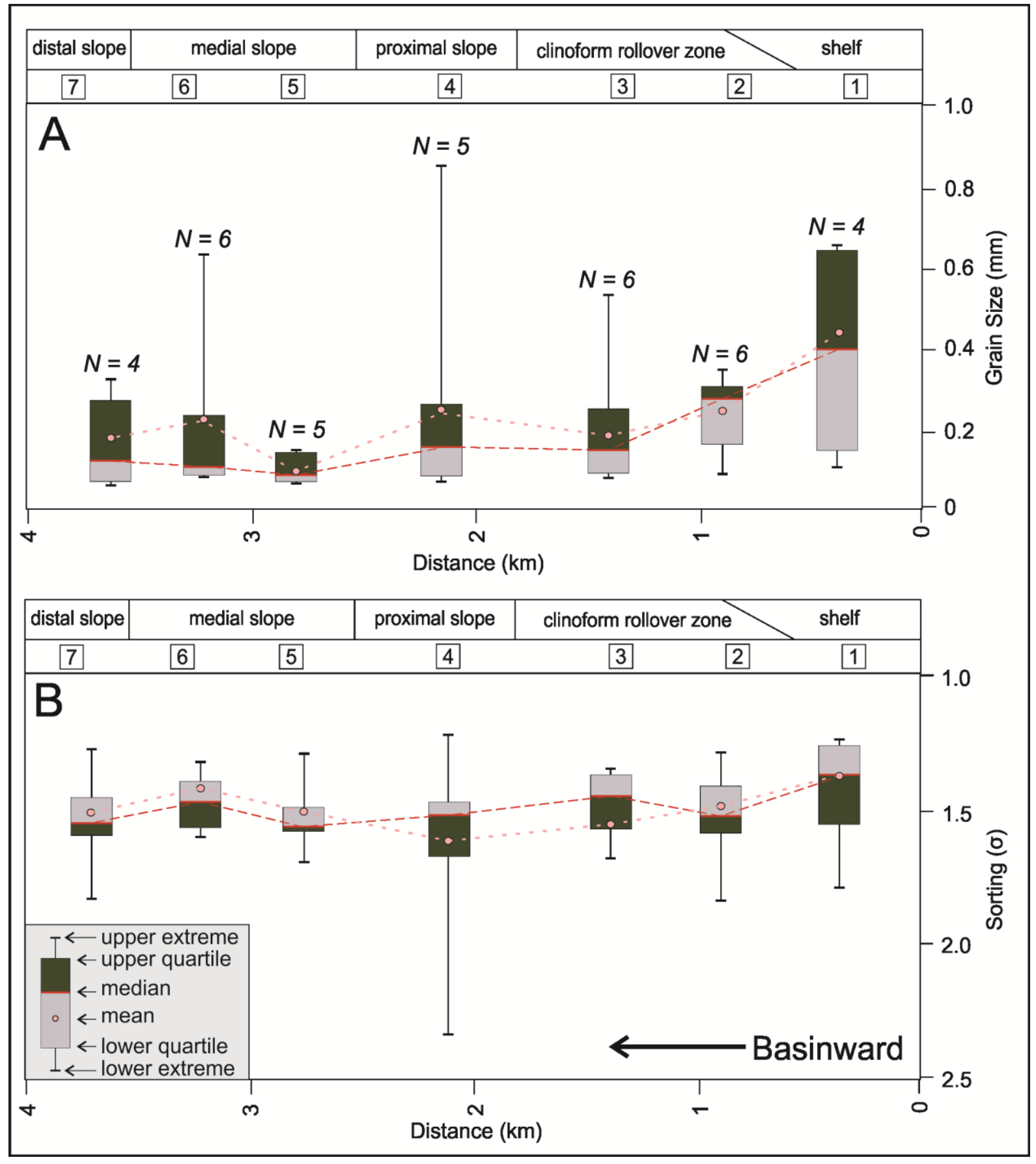

This article is protected by copyright. All rights reserved. 


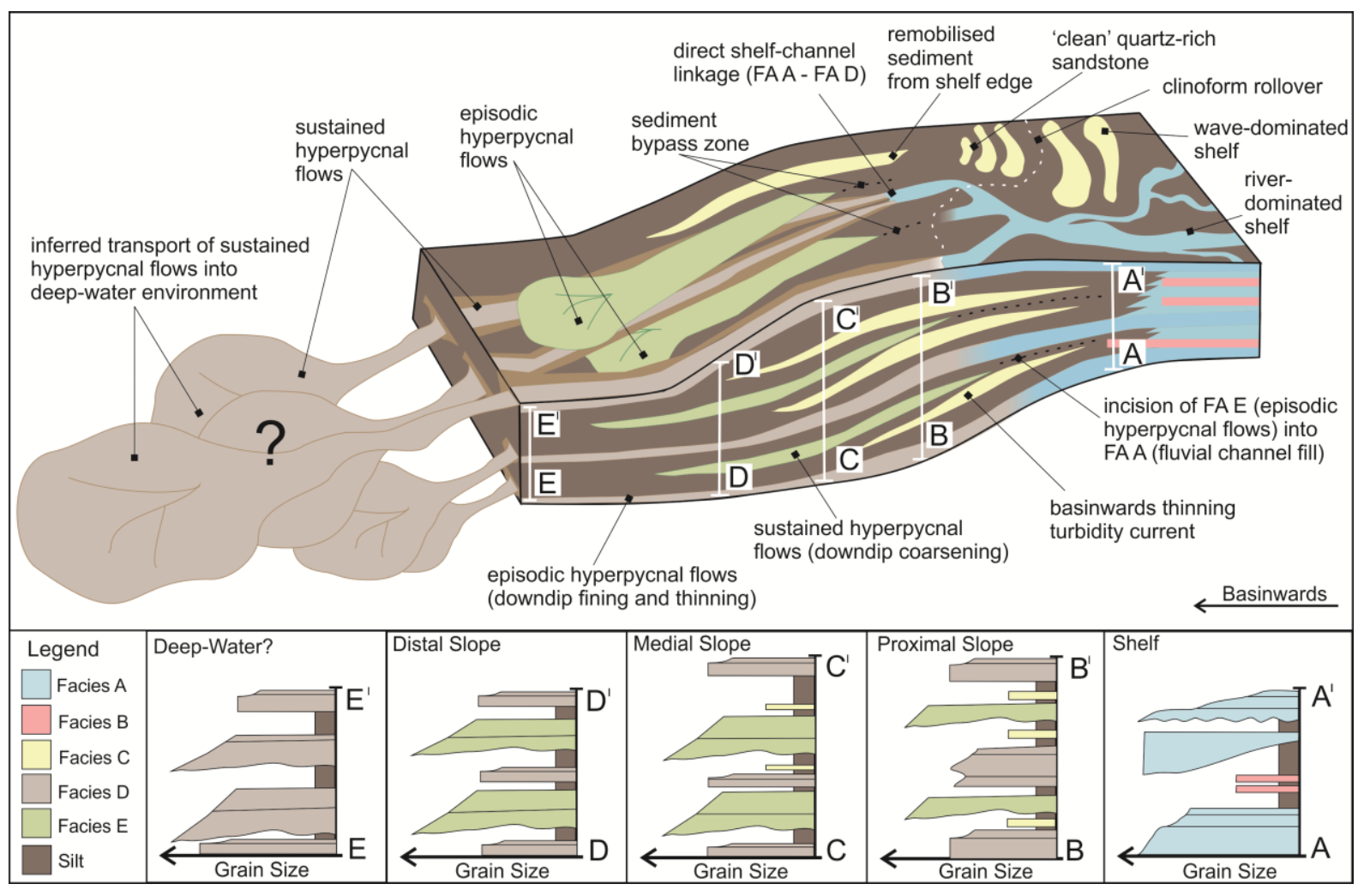

This article is protected by copyright. All rights reserved. 